\title{
One-year simulation of ozone and particulate matter in China using WRF/CMAQ modeling system
}

\author{
Jianlin $\mathrm{Hu}^{1}$, Jianjun Chen ${ }^{2,1}$, Qi Ying ${ }^{3,1}$, and Hongliang Zhang ${ }^{4,1}$ \\ ${ }^{1}$ Jiangsu Key Laboratory of Atmospheric Environment Monitoring and Pollution Control, Jiangsu Engineering Technology \\ Research Center of Environmental Cleaning Materials, Collaborative Innovation Center of Atmospheric Environment and \\ Equipment Technology, School of Environmental Science and Engineering, Nanjing University of Information Science and \\ Technology, 219 Ningliu Road, Nanjing 210044, China \\ ${ }^{2}$ Air Quality Planning and Science Division, California Air Resources Board, 1001 I Street, Sacramento, CA 95814, USA \\ ${ }^{3}$ Zachry Department of Civil Engineering, Texas A\&M University, College Station, TX 77843, USA \\ ${ }^{4}$ Department of Civil and Environmental Engineering, Louisiana State University, Baton Rouge, LA 70803, USA
}

Correspondence to: Qi Ying (qying@ civil.tamu.edu) and Hongliang Zhang (hlzhang@ lsu.edu)

Received: 17 February 2016 - Published in Atmos. Chem. Phys. Discuss.: 13 April 2016

Revised: 15 July 2016 - Accepted: 18 July 2016 - Published: 16 August 2016

\begin{abstract}
China has been experiencing severe air pollution in recent decades. Although an ambient air quality monitoring network for criteria pollutants has been constructed in over 100 cities since 2013 in China, the temporal and spatial characteristics of some important pollutants, such as particulate matter (PM) components, remain unknown, limiting further studies investigating potential air pollution control strategies to improve air quality and associating human health outcomes with air pollution exposure. In this study, a yearlong (2013) air quality simulation using the Weather Research and Forecasting (WRF) model and the Community Multi-scale Air Quality (CMAQ) model was conducted to provide detailed temporal and spatial information of ozone $\left(\mathrm{O}_{3}\right)$, total $\mathrm{PM}_{2.5}$, and chemical components. Multi-resolution Emission Inventory for China (MEIC) was used for anthropogenic emissions and observation data obtained from the national air quality monitoring network were collected to validate model performance. The model successfully reproduces the $\mathrm{O}_{3}$ and $\mathrm{PM}_{2.5}$ concentrations at most cities for most months, with model performance statistics meeting the performance criteria. However, overprediction of $\mathrm{O}_{3}$ generally occurs at low concentration range while underprediction of $\mathrm{PM}_{2.5}$ happens at low concentration range in summer. Spatially, the model has better performance in southern China than in northern China, central China, and Sichuan Basin. Strong seasonal variations of $\mathrm{PM}_{2.5}$ exist and wind speed and direction play important roles in high
\end{abstract}

$\mathrm{PM}_{2.5}$ events. Secondary components have more boarder distribution than primary components. Sulfate $\left(\mathrm{SO}_{4}^{2-}\right)$, nitrate $\left(\mathrm{NO}_{3}^{-}\right)$, ammonium $\left(\mathrm{NH}_{4}^{+}\right)$, and primary organic aerosol (POA) are the most important $\mathrm{PM}_{2.5}$ components. All components have the highest concentrations in winter except secondary organic aerosol (SOA). This study proves the ability of the CMAQ model to reproduce severe air pollution in China, identifies the directions where improvements are needed, and provides information for human exposure to multiple pollutants for assessing health effects.

\section{Introduction}

Atmospheric pollutants have adverse effects on human health and ecosystems and are associated with climate change (Menon et al., 2008; Pöschl, 2005; Pui et al., 2014). Developing countries usually experience severely high concentrations of air pollutants due to fast growth of population, industrialization, transportation, and urbanization without prompt emission controls. As one of such countries, China started to publish real-time concentration data of six criteria pollutants from the ambient air quality monitoring networks after multiple severe pollution events across the country (Sun et al., 2014; M. Tao et al., 2014; D. Wang et al., 2014; Zheng et al., 2015). 
More than 1000 observation sites have been set up in more than 100 major cities in the country to routinely monitor hourly concentrations of six criteria pollutants, i.e., $\mathrm{O}_{3}, \mathrm{CO}$, $\mathrm{NO}_{2}, \mathrm{SO}_{2}, \mathrm{PM}_{2.5}$ (PM - particulate matter), and $\mathrm{PM}_{10}$, and to inform the public on air quality status using the air quality index (AQI). Analysis of the observation provided a general understanding of the spatial and temporal variation of the levels of air pollution (Hu et al., 2014a; Y. Wang et al., 2014), the roles of meteorology in air pollution (H. Zhang et al., 2015), and the construction of AQI based on multiple pollutants to better inform the public about the severity of air pollution (Hu et al., 2015b). However, the monitoring system only considers criteria pollutants and the key species such as the volatile organic compounds (VOCs) and the chemical composition of PM that are needed to understand the causes of air pollution and form cost-effective emissions controls are not measured routinely. Monitoring networks focusing on the chemical composition of gaseous and particulate air pollutants, such as the Photochemical Assessment Monitoring Stations (PAMS) and the Chemical Speciation Network (CNS) in the United States, have not been established in China. The lack of detailed chemical composition information limits our capability to understand the formation mechanisms of $\mathrm{O}_{3}$ and PM, quantify the contributions of different sources, and design effective control strategies. In addition, the observation sites are mostly in highly developed urban areas but are very sparse in other suburban and rural regions which also have large population and experience high concentrations of certain pollutants, such as $\mathrm{O}_{3}$. Insufficient spatial coverage in the monitoring system limits the completeness of public air pollution risk assessment for the entire country.

Chemical transport models (CTMs) are often used to reproduce past pollution events, test newly discovered atmospheric mechanisms, predict future air quality, and provide high temporal and spatial resolution data for epidemiological studies. Several modeling studies have been reported to analyze the severe air pollution events in January 2013. For example, the Community Multiscale Air Quality (CMAQ) model was updated with heterogeneous chemistry to study the formation of secondary inorganic aerosol in northern China (Zheng et al., 2015). The CMAQ model was also applied to identify the contributions of both source regions and sectors to $\mathrm{PM}_{2.5}$ in southern Hebei during the 2013 severe haze episode with a brute force method (L. T. Wang et al., 2014). It was found that industrial and domestic activities were the most significant local sectors while northern Hebei province, Beijing-Tianjin city cluster, and Henan province were the major regional contributors. Using the two-way coupled Weather Research and Forecasting (WRF)/CMAQ system, L. T. Wang et al. (2014) simulated the impacts of aerosol-meteorology interactions of the PM pollution during January 2013. They argued that enhanced planetary boundary layer stability suppressed the dispersion of air pollutants and resulted in higher $\mathrm{PM}_{2.5}$ concentrations. Similar results were also reported by B. Zhang et al. (2015) with the WRF/Chemistry (WRF/Chem) model. Using the Comprehensive Air Quality Model with extensions (CAMx) and the Particulate Source Apportionment Technology (PSAT), X. Li et al. (2015) determined the contributions of 7 emission categories and 11 source regions to regional air pollution in China and suggested a strong need for regional joint emission control efforts in Beijing. More recently, Hu et al. (2015a) used a tracer-based technique in a source-oriented CMAQ to determine source sector/region contributions to primary PM in different seasons in 2012-2013. It was found that residential and industrial emissions from local area and the neighboring Hebei province contribute to high primary PM events in Beijing.

All above modeling studies except $\mathrm{Hu}$ et al. (2015a) were focused on the formation and source apportionment of airborne PM during the severe pollution episode of January 2013 in northern China. Although additional PM formation pathways and/or emission adjustments were implemented and tuned to better predict this extreme episode, model predictions were only evaluated against a small number of measurements in and near Beijing for a relatively short period of time. A few studies have been conducted to evaluate the model performance in China for longer time periods, such as a full year or several representative months in different seasons (Gao et al., 2014; Liu et al., 2010; Liu et al., 2016; Wang et al., 2011; Zhang et al., 2016; Zhao et al., 2013b). However, due to limited ambient observation data, model performance on temporal and spatial variations of air pollutants were mostly evaluated against available surface observation at a limited number of sites. In addition, the surface observations were mostly based on the air pollution index numbers of the Ministry of Environmental Protection (MEP), which could be used to calculate the concentrations of the major pollutants of $\mathrm{SO}_{2}, \mathrm{NO}_{2}$, or $\mathrm{PM}_{10}$. Extensive model performance evaluation of $\mathrm{O}_{3}$ and $\mathrm{PM}$ is urgently needed to build the confidence in the emission inventory, the predicted meteorological fields, as well as the capability of the model in predicting regional $\mathrm{O}_{3}$ and PM under a wide range of topographical, meteorological, and emission conditions so that further modeling studies of pollutant formation mechanisms, emission control strategies, and human exposure and health risk assessment are based on a solid foundation.

In this study, a yearlong (2013) air quality simulation using a WRF/CMAQ system was conducted to provide detailed temporal and spatial distribution of $\mathrm{O}_{3}$ and $\mathrm{PM}$ concentrations as well as $\mathrm{PM}_{2.5}$ chemical composition in China. The publicly available observation data obtained from a total of 422 air monitoring sites in 60 major cities in China were used to provide a thorough evaluation of the model performance in the entire year. The modeled spatial and temporal concentrations of $\mathrm{O}_{3}$ and $\mathrm{PM}_{2.5}$ from this study will be used in subsequent studies to investigate the interaction between $\mathrm{O}_{3}$ and PM pollution during high pollution events, the formation 
mechanism of secondary inorganic and organic aerosols, and the population exposure and health risk.

\section{Method}

\subsection{Model description}

The CMAQ model applied in this study is based on CMAQ v5.0.1. Changes were made to the original CMAQ to improve the capability of the model in predicting secondary inorganic and organic aerosol, including (1) a modified SAPRC-11 gas phase photochemical mechanism to provide more detailed treatment of isoprene oxidation chemistry (Ying et al., 2015); (2) pathways of secondary organic aerosol (SOA) formation from surface controlled reactive uptake of dicarbonyls, isoprene epoxydiol (IEPOX), and methacrylic acid epoxide (MAE) (J. Li et al., 2015; Ying et al., 2015); (3) vapor wallloss corrected SOA yields (Zhang et al., 2014b); and (4) heterogeneous reactions of $\mathrm{NO}_{2}$ and $\mathrm{SO}_{2}$ on particle surface to form secondary nitrate and sulfate (Ying et al., 2014a). More details of these changes can be found in the cited references and the references therein, and thus only a short summary of the changes are provided below.

The isoprene mechanism in the original SAPRC-11 with standard lumping (Carter and Heo, 2012) was replaced by the detailed isoprene oxidation chemistry as used by Lin et al. (2013) to predict the formation of IEPOX and MAE in the gas phase. A precursor tracking scheme was implemented in the modified SAPRC-11 to track the glyoxal (GLY) and methylglyoxal (MGLY) formation from multiple biogenic and anthropogenic precursors. The surface controlled reactive uptake of SOA precursors is considered non-reversible, with constant uptake coefficients for GLY and MGLY as used by $\mathrm{Fu}$ et al. (2008) and an acidity-dependent uptake coefficient for IEPOX and MAE as described by J. Li et al. (2015). The original SOA yields for toluene and xylene under high $\mathrm{NO}_{x}$ concentrations based on $\mathrm{Ng}$ et al. (2007) were replaced with the higher toluene yield reported by Hildebrandt et al. (2009). This update has been applied by Ying et al. (2014a) to study SOA formation in Mexico City. All SOA yields were then corrected by the average bias due to wall loss as reported in Table 1 of X. Zhang et al. (2014). A modeling study of SOA formation in eastern USA reported by Ying et al. (2015) shows that negative bias in predicted organic carbon concentrations reported in previous studies have been significantly reduced. Formation of sulfate and nitrate due to heterogeneous reactions on particle surface is also modeled as a reactive uptake process. The reactive surface uptake coefficients of $\mathrm{SO}_{2}$ and $\mathrm{NO}_{2}$ on particle surface were taken from Ying et al. (2014a) and Zheng et al. (2015) respectively.

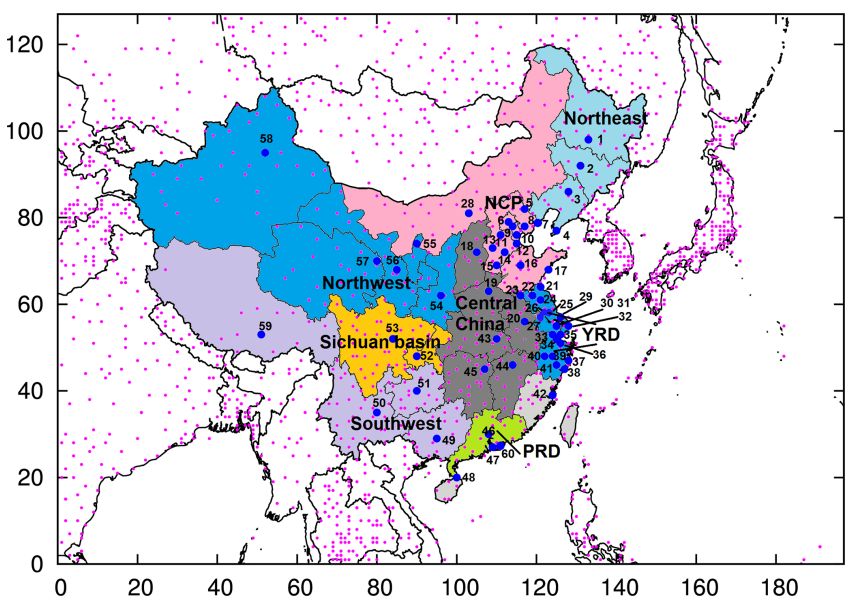

Figure 1. Model domain. The axes are the number of grid cells. Blue filled circles show the locations of cities with air quality observations (see Table 2). The purple dots show the locations of meteorological stations. The figure also shows the regions discussed in the text for better understanding. NCP represents North China Plain, YRD represents Yangtze River Delta, and PRD represents Pearl River Delta.

\subsection{Model application}

The updated CMAQ model was applied to simulate $\mathrm{O}_{3}$ and particulate air pollution using a $36 \mathrm{~km} \times 36 \mathrm{~km}$ horizontal resolution domain that covers China and surrounding countries in East Asia (Fig. 1). The meteorological inputs were generated using WRF v3.6.1 with initial and boundary conditions from the NCEP FNL Operational Model Global Tropospheric Analyses dataset. Detailed WRF model configurations have been described by Zhang et al. (2012).

Multi-resolution Emission Inventory for China (MEIC) $\left(0.25^{\circ} \times 0.25^{\circ}\right)$ developed by Tsinghua University (http: //www.meicmodel.org) was used for the monthly anthropogenic emissions from China. MEIC (V1.0) is the new version of emission inventory in China, including improvements such as a unit-based emission inventory for power plants (Wang et al., 2012) and cement plants (Lei et al., 2011), a high-resolution county-level vehicle emission inventory (Zheng et al., 2014), and a non-methane VOC mapping approach for different chemical mechanisms (M. Li et al., 2014). MEIC provides speciated VOC emissions for the SAPRC-07 mechanism with standard lumping (Carter, 2010). As the definitions of explicit and lumped primary VOCs have not changed from SAPRC-07 to SAPRC-11, these VOC emissions were directly used to drive SAPRC11. Total $\mathrm{PM}_{2.5}$ mass emissions and emissions of primary organic carbon and elemental carbon (EC) were also provided by MEIC directly. Emissions of trace metals needed by version 6 of the aerosol module in CMAQ (AERO6) were generated using averaged speciation profiles adapted from the US Environmental Protection Agency (EPA) SPE- 
CIATE database for each MEIC source category. Emissions from other countries and regions rather than China in the domain were filled with data generated from the gridded $0.25^{\circ} \times 0.25^{\circ}$ resolution Regional Emission inventory in ASia version 2 (REAS2) (Kurokawa et al., 2013). Details of the REAS2 emission processing are described by Qiao et al. (2015). Detailed information about spatial and temporal allocation can also be found in the papers cited above.

Biogenic emissions were generated using the Model for Emissions of Gases and Aerosols from Nature (MEGAN) v2.1. The leaf area index (LAI) was based on the 8 day Moderate Resolution Imaging Spectroradiometer (MODIS) LAI product (MOD15A2) and the plant function types (PFTs) were based on the PFT files used in the Global Community Land Model (CLM 3.0). For more details of the biogenic emission processing, the readers are referred to Qiao et al. (2015). Open biomass burning emissions were generated from the Fire INventory from NCAR (FINN), which is based on satellite observations (Wiedinmyer et al., 2011). Dust and sea salt emissions were generated in line during the CMAQ simulations. In this updated CMAQ model, dust emission module was updated to be compatible with the 20category MODIS land use data (Hu et al., 2015a). Initial and boundary conditions were based on the default vertical distributions of concentrations that represent clean continental conditions as provided by the CMAQ model. The impact of initial conditions was minimal as the results of the first 5 days of the simulation were excluded in the analyses.

\section{Results}

\subsection{Meteorology validation}

Meteorological factors are closely related to transport, transformation, and deposition of air pollutants (Hu et al., 2014b; Jacob and Winner, 2009; J. Tao et al., 2014; H. Zhang et al., 2015). Although the WRF model has been widely used to provide meteorological inputs for CTMs, the performance varies when applying to different domains, episodes, and with different model settings. Thus, the validation of model performance on meteorological conditions is important in assuring the accuracy of air quality predictions. Observation data from the National Climate Data Center (NCDC) was used to validate the model predictions of temperature (T2) and relative humidity (RH) at $2 \mathrm{~m}$ above surface, and wind speed (WS) and wind direction (WD) at $10 \mathrm{~m}$ above surface. Within the domain, there are $\sim 1200$ stations shown as purple dots in Fig. 1. Model performance statistics of mean observation (OBS), mean prediction (PRE), mean bias (MB), gross error (GE), and root mean square error (RMSE) based on the observations and WRF predictions at the grid cells where the stations are located are shown in Table 1. The table also shows the benchmarks suggested by Emery et al. (2001) for the MM5 model in the eastern USA with 4-12 km grid resolution.

The WRF model predicts slightly higher $\mathrm{T} 2$ in winter and lower $\mathrm{T} 2$ in other seasons than the observations. The MB values for June, July, and September to December are within the benchmark, but the GE values of T2 are generally larger than the benchmark. The GE values of WS meet the benchmark in all months, but WS is overpredicted, as indicated by the positive MB values. The MB values meet the benchmark in January, June, and August, and RMSE values are within the benchmark in June, July, and August. MB values of WD are within the benchmark of $\pm 10^{\circ}$ for 4 months. February, November, and December are the months with largest MB values. All GE values of WD are about $50 \%$ larger than the benchmark. RH is generally underpredicted except for July and August. The performance in this study is comparable to other studies using WRF in China (Hu et al., 2015a; Wang et al., 2010; Wang et al., 2014b; Ying et al., 2014b; Zhang et al., 2012), despite the differences in model, resolution, and study region in different studies. Generally, the WRF model has acceptable performance on meteorological parameters. It should be noted that there is a study showing better WRF performance (Zhao et al., 2013a). However, it is difficult to compare since different model settings, simulation episodes, and number of observation stations were used.

\subsection{Model performance of $\mathrm{O}_{3}$ and $\mathrm{PM}_{2.5}$}

Hourly observations of air pollutants from March to December 2013 were obtained from the publishing website of China National Environmental Monitoring Center (http: //113.108.142.147:20035/emcpublish/). A total of 422 stations in 60 cities (see Fig. 1 for the location of the cities) including the capital cities of all 31 provinces were obtained. Concentrations of pollutants in difference regions of China exhibit large variations due to diverse climates, topography, and emission sources. Aiming to identify the model strength and weakness in different regions of China, model performance was evaluated separately for different regions. The regions and names of these cities are listed in Table 2. Automated quality control measures were taken to remove data points with observed $\mathrm{O}_{3}$ concentrations greater than $250 \mathrm{ppb}$, $\mathrm{PM}_{2.5}$ concentrations greater than $1500 \mu \mathrm{g} \mathrm{m}^{-3}$, and points with standard deviation less than $5 \mathrm{ppb}$ or $5 \mu \mathrm{g} \mathrm{m}^{-3}$ in $24 \mathrm{~h}$.

\subsection{1 $\mathrm{O}_{3}$ model performance}

Table 3 shows the model performance statistics of gaseous pollutants $\left(1 \mathrm{~h}\right.$ peak $\mathrm{O}_{3}\left(\mathrm{O}_{3}-1 \mathrm{~h}\right), 8 \mathrm{~h}$ peak $\mathrm{O}_{3}\left(\mathrm{O}_{3}-8 \mathrm{~h}\right)$, and hourly $\mathrm{CO}, \mathrm{NO}_{2}$, and $\mathrm{SO}_{2}$ ), $\mathrm{PM}_{2.5}$, and $\mathrm{PM}_{10}$. Mean observations, mean predictions, mean fractional bias (MFB), mean fractional error (MFE), mean normalized bias (MNB), and mean normalized error (MNE) of hourly concentrations are calculated for each month from March to December 2013. Only $\mathrm{O}_{3}-1 \mathrm{~h}$ or $\mathrm{O}_{3}-8 \mathrm{~h}$ concentrations greater than $30 \mathrm{ppb}$ 
Table 1. Meteorology performance in all the months in 2013 (OBS is mean observation; PRE is mean prediction; MB is mean bias; GE is gross error; RMSE is root mean square error). The benchmarks are suggested by Emery et al. (2001) for the MM5 model in the eastern USA with $4-12 \mathrm{~km}$ grid resolution. The values that do not meet the criteria are denoted in bold.

\begin{tabular}{|c|c|c|c|c|c|c|c|c|c|c|c|c|c|c|}
\hline & & Jan & Feb & Mar & Apr & May & Jun & Jul & Aug & Sep & Oct & Nov & Dec & Bench-mark \\
\hline \multirow[t]{5}{*}{$\mathrm{T} 2$} & OBS & 267.3 & 270.4 & 277.5 & 282.7 & 289.3 & 293.9 & 297.0 & 297.1 & 292.1 & 286.0 & 278.1 & 272.8 & \\
\hline & PRE & 266.1 & 268.9 & 276.2 & 281.8 & 288.7 & 293.6 & 296.5 & 296.5 & 291.9 & 286.0 & 278.4 & 273.1 & \\
\hline & MB & 1.2 & -1.4 & -1.3 & -0.8 & -0.7 & -0.3 & -0.5 & -0.6 & -0.2 & 0.0 & 0.3 & 0.3 & $\leq \pm 0.5$ \\
\hline & GE & 3.7 & 3.3 & 3.0 & 2.7 & 2.7 & 2.7 & 2.6 & 2.5 & 2.4 & 2.5 & 2.7 & 2.8 & $\leq \mathbf{2 . 0}$ \\
\hline & RMSE & 4.7 & 4.5 & 4.0 & 3.6 & 3.5 & 3.6 & 3.5 & 3.3 & 3.2 & 3.3 & 3.5 & 3.8 & \\
\hline \multirow[t]{5}{*}{$\mathrm{WS}\left(\mathrm{ms}^{-1}\right)$} & OBS & 3.0 & 3.5 & 3.7 & 3.8 & 3.6 & 3.3 & 3.4 & 3.2 & 3.3 & 3.4 & 3.5 & 3.5 & \\
\hline & PRE & 3.2 & 4.8 & 4.8 & 4.8 & 4.4 & 3.8 & 4.0 & 3.8 & 4.0 & 4.4 & 4.6 & 4.7 & \\
\hline & MB & 0.2 & 1.3 & 1.1 & 1.0 & 0.7 & 0.5 & 0.6 & 0.5 & 0.7 & 1.0 & 1.1 & 1.2 & $\leq \pm 0.5$ \\
\hline & GE & 1.3 & 2.0 & 1.9 & 1.9 & 1.7 & 1.53 & 1.6 & 1.5 & 1.6 & 1.7 & 1.9 & $1 . .9$ & $\leq 2.0$ \\
\hline & RMSE & 2.6 & 2.6 & 2.5 & 2.4 & 2.2 & 2.0 & 2.0 & 1.9 & 2.1 & 2.3 & 2.4 & 2.5 & $\leq 2.0$ \\
\hline \multirow[t]{5}{*}{ WD } & OBS & 187.5 & 212.0 & 205.0 & 202.4 & 187.3 & 171.2 & 187.0 & 190.6 & 174.8 & 183.0 & 216.0 & 216.4 & \\
\hline & PRE & 209.9 & 229.1 & 220.4 & 216.8 & 198.5 & 175.8 & 200.8 & 203.4 & 171.4 & 182.1 & 236.5 & 234.0 & \\
\hline & MB & 10.5 & 17.1 & 15.4 & 14.4 & 11.2 & 4.6 & 13.8 & 12.9 & -3.4 & -0.9 & 20.5 & 17.7 & $\leq \pm 10$ \\
\hline & GE & 46.3 & 47.7 & 46.7 & 44.8 & 46.2 & 49.4 & 46.6 & 47.4 & 47.5 & 45.6 & 44.8 & 46.6 & $\leq \pm 30$ \\
\hline & RMSE & 66.3 & 65.1 & 64.1 & 62.1 & 63.4 & 66.4 & 63.5 & 64.4 & 65.0 & 62.9 & 61.8 & 63.8 & \\
\hline \multirow[t]{5}{*}{$\mathrm{RH}$} & OBS & 64.9 & 78.9 & 69.5 & 67.1 & 64.3 & 68.7 & 70.8 & 70.4 & 6938 & 71.7 & 72.2 & 75.3 & \\
\hline & PRE & 63.6 & 73.4 & 68.4 & 65.3 & 64.0 & 68.1 & 72.0 & 72.1 & 69.2 & 71.0 & 68.9 & 68.7 & \\
\hline & MB & -1.4 & -5.6 & -1.1 & -1.8 & -0.3 & -0.5 & 1.2 & 1.7 & -0.6 & -0.7 & -3.3 & -6.5 & \\
\hline & GE & 19.2 & 14.1 & 15.4 & 14.9 & 14.5 & 13.4 & 13.5 & 13.0 & 12.6 & 13.5 & 14.1 & 14.8 & \\
\hline & RMSE & 21.2 & 18.3 & 19.4 & 18.9 & 18.6 & 17.4 & 17.3 & 16.6 & 16.3 & 17.4 & 18.4 & 19.8 & \\
\hline
\end{tabular}

Table 2. List of the cities in different regions with available observations.

\begin{tabular}{ll}
\hline Region & City list \\
\hline Northeast (4 cities) & 1. Harbin, 2. Changchun, 3. Shenyang, 4. Dalian \\
North China Plain (NCP) (14) & 5. Chengde, 6. Beijing, 7. Qinhuangdao, 8. Tangshan, 9. Langfang, 10. Tianjin, 11. Baoding, \\
& 12. Cangzhou, 13. Shijiazhuang, 14. Hengshui, 15. Handan, 16. Jinan, 17. Qingdao, 28. Hohhot \\
Yangtze River Delta (YRD) (20) & 21. Lianyungang, 22. Suqian, 23. Xuzhou, 24. Huai' an, 25. Taizhou, 26. Yangzhou, 27. Nanjing, \\
& 29. Nantong, 30. Suzhou, 31. Wuxi, 32. Shanghai, 33. Huzhou, 34. Hangzhou, 35. Jiaxing, 36. \\
& Shaoxing, 37. Zhoushan, 38. Wenzhou, 39. Jinhua, 40. Quzhou, 41. Lishui \\
Pearl River Delta (PRD) (3) & 46. Guangzhou, 47. Zhuhai, 60. Shenzhen \\
Central China (6) & 18. Taiyuan, 19. Zhengzhou, 20. Hefei, 43. Wuhan, 44. Nanchang, 45. Changsha \\
Northwest (5) & 54. Xi'an, 55. Yinchuan, 56. Lanzhou, 57. Xining, 58. Ürümqi \\
Sichuan Basin (SCB) (2) & 52. Chongqing, 53. Chengdu \\
Southwest and other (6) & 42. Fuzhou, 48. Haikou, 49. Nanning, 50. Kunming, 51. Guiyang, 59. Lhasa \\
\hline
\end{tabular}

were included in the analysis. A cutoff concentration of 40 or $60 \mathrm{ppb}$ is suggested by the US EPA (EPA, 2005). A lower cutoff of $30 \mathrm{ppb}$ is chosen in this study considering the monitoring sites are all located in urban areas and higher $\mathrm{O}_{3}$ concentrations generally occur in downwind of urban areas. The overall model performance on $\mathrm{O}_{3}-1 \mathrm{~h}$ and $\mathrm{O}_{3}-8 \mathrm{~h}$ meets the model performance criteria suggested by US EPA (2005) in all months, except in March and April for $\mathrm{O}_{3}-1 \mathrm{~h}$ and June for $\mathrm{O}_{3}-8 \mathrm{~h}$. MNE of $\mathrm{O}_{3}-1 \mathrm{~h}$ in June and July slightly exceeds the criteria, although MNB meets the criteria. $\mathrm{MNB}$ of $\mathrm{O}_{3}$ $8 \mathrm{~h}$ in May exceeds the criteria, but MNE meets the criteria. The relatively small MNB/MNE and MFB/MFE in most of months indicate that $\mathrm{O}_{3}-1 \mathrm{~h}$ and $\mathrm{O}_{3}-8 \mathrm{~h}$ are well captured.
Model performance of $\mathrm{O}_{3}-1 \mathrm{~h}$ and $\mathrm{O}_{3}-8 \mathrm{~h}$ in different regions is illustrated in Table 4. Model performance meets the criteria in four regions, i.e., North China Plain (NCP), Yangtze River Delta (YRD), Pearl River Delta (PRD), and northeast (NE). Relatively poor performance is identified in the Sichuan Basin (SCB), central (CEN), and northwestern (NW) regions. $\mathrm{O}_{3}-1 \mathrm{~h}$ and $\mathrm{O}_{3}-8 \mathrm{~h}$ concentrations are slightly underpredicted in YRD and PRD but overpredicted in all other regions. Model performance in regions other than NCP and YRD should be interpreted with care due to limited number of cities to sufficiently represent the entire region.

Figure 2 compares the predicted monthly averaged diurnal variations of $\mathrm{O}_{3}$ concentrations with observations for all 60 cities. For a city with multiple stations, observations and 
Table 3. Model performance on $\mathrm{O}_{3}-1 \mathrm{~h}, \mathrm{O}_{3}-8 \mathrm{~h}, \mathrm{PM}_{2.5}, \mathrm{PM}_{10}, \mathrm{CO}, \mathrm{NO}_{2}$, and $\mathrm{SO}_{2}$ in March to December 2013 (OBS is mean observation; PRE is mean prediction; MFB is mean fractional bias; MFE is mean fractional error; MNB is mean normalized bias; MNE is mean normalized error). The performance criteria for $\mathrm{PM}_{2.5}$ are suggested by EPA (2007), and the performance criteria for $\mathrm{O}_{3}$ are suggested by EPA (2005). The values that do not meet the criteria are denoted in bold.

\begin{tabular}{|c|c|c|c|c|c|c|c|c|c|c|c|c|}
\hline & & Mar & Apr & May & Jun & Jul & Aug & Sep & Oct & Nov & Dec & Criteria \\
\hline \multirow[t]{6}{*}{$\mathrm{O}_{3}-1 \mathrm{~h}(\mathrm{ppb})$} & OBS & 53.96 & 57.73 & 65.37 & 67.72 & 65.7 & 68.3 & 60.73 & 57.97 & 49.18 & 46.53 & \\
\hline & PRE & 58.09 & 61.76 & 66.91 & 67.82 & 63.23 & 66.47 & 59.5 & 54.92 & 45.66 & 42.09 & \\
\hline & MFB & 0.08 & 0.09 & 0.05 & 0.01 & -0.01 & -0.01 & 0.01 & -0.03 & -0.05 & -0.09 & \\
\hline & MFE & 0.29 & 0.27 & 0.25 & 0.3 & 0.29 & 0.28 & 0.27 & 0.26 & 0.27 & 0.32 & \\
\hline & MNB & 0.16 & 0.17 & 0.11 & 0.1 & 0.06 & 0.06 & 0.07 & 0.03 & 0.01 & -0.01 & $\leq \pm 0.15$ \\
\hline & MNE & 0.34 & 0.32 & 0.28 & 0.33 & 0.31 & 0.3 & 0.29 & 0.26 & 0.26 & 0.28 & $\leq 0.3$ \\
\hline \multirow[t]{6}{*}{$\mathrm{O}_{3}-8 \mathrm{~h}(\mathrm{ppb})$} & OBS & 50.4 & 47.44 & 52.59 & 54.36 & 51.79 & 54.03 & 48.63 & 48.03 & 40.31 & 38.92 & \\
\hline & PRE & 48.81 & 51.49 & 57.86 & 59.58 & 54.05 & 58.07 & 50.64 & 48.48 & 40.6 & 40.7 & \\
\hline & MFB & -0.05 & 0.07 & 0.1 & 0.08 & 0.03 & 0.06 & 0.04 & 0.01 & -0.01 & 0.01 & \\
\hline & MFE & 0.29 & 0.24 & 0.24 & 0.28 & 0.26 & 0.26 & 0.25 & 0.24 & 0.25 & 0.27 & \\
\hline & MNB & 0.03 & 0.13 & 0.16 & 0.16 & 0.09 & 0.12 & 0.1 & 0.06 & 0.03 & 0.07 & $\leq \pm 0.15$ \\
\hline & MNE & 0.29 & 0.28 & 0.28 & 0.32 & 0.28 & 0.29 & 0.27 & 0.25 & 0.24 & 0.27 & $\leq 0.3$ \\
\hline \multirow[t]{6}{*}{$\mathrm{PM}_{2.5}\left(\mu \mathrm{g} \mathrm{m}^{-3}\right)$} & OBS & 81.68 & 62.07 & 60.12 & 60.83 & 45.52 & 47.1 & 56.08 & 85.69 & 88.93 & 123.73 & \\
\hline & PRE & 66.12 & 43.24 & 39.28 & 41.6 & 31.31 & 39.07 & 52.24 & 56.09 & 80.21 & 126.83 & \\
\hline & MFB & -0.24 & -0.4 & -0.47 & -0.41 & -0.48 & -0.31 & -0.21 & -0.42 & -0.17 & -0.07 & $\leq \pm 0.6$ \\
\hline & MFE & 0.59 & 0.63 & 0.68 & 0.69 & 0.72 & 0.65 & 0.62 & 0.64 & 0.6 & 0.59 & $\leq 0.75$ \\
\hline & MNB & 0.04 & -0.16 & -0.19 & -0.09 & -0.17 & -0.01 & 0.11 & -0.16 & 0.17 & 0.3 & \\
\hline & MNE & 0.61 & 0.54 & 0.58 & 0.63 & 0.63 & 0.64 & 0.68 & 0.56 & 0.7 & 0.75 & \\
\hline \multirow[t]{6}{*}{$\mathrm{PM}_{10}\left(\mu \mathrm{g} \mathrm{m}^{-3}\right)$} & OBS & 151.39 & 121.56 & 111.90 & 96.95 & 79.90 & 85.04 & 98.27 & 136.02 & 150.27 & 178.78 & \\
\hline & PRE & 74.72 & 52.48 & 45.37 & 46.58 & 35.59 & 44.63 & 57.53 & 65.12 & 90.22 & 136.26 & \\
\hline & MFB & -0.59 & -0.73 & -0.79 & -0.68 & -0.78 & -0.65 & -0.54 & -0.65 & -0.48 & -0.34 & \\
\hline & MFE & 0.74 & 0.83 & 0.89 & 0.82 & 0.88 & 0.79 & 0.73 & 0.77 & 0.72 & 0.63 & \\
\hline & MNB & -0.31 & -0.43 & -0.45 & -0.35 & -0.44 & -0.35 & -0.24 & -0.36 & -0.16 & -0.04 & \\
\hline & MNE & 0.56 & 0.58 & 0.62 & 0.62 & 0.63 & 0.59 & 0.60 & 0.59 & 0.64 & 0.62 & \\
\hline \multirow[t]{6}{*}{$\mathrm{CO}(\mathrm{ppm})$} & OBS & 1.17 & 0.94 & 0.86 & 0.8 & 0.73 & 0.75 & 0.85 & 1.09 & 1.16 & 1.48 & \\
\hline & PRE & 0.37 & 0.26 & 0.25 & 0.26 & 0.23 & 0.25 & 0.29 & 0.31 & 0.41 & 0.59 & \\
\hline & MFB & -0.89 & -0.97 & -0.97 & -0.91 & -0.95 & -0.92 & -0.9 & -0.98 & -0.88 & -0.8 & \\
\hline & MFE & 0.95 & 1.01 & 1 & 0.95 & 0.99 & 0.96 & 0.95 & 1.02 & 0.92 & 0.86 & \\
\hline & MNB & -0.54 & -0.6 & -0.6 & -0.56 & -0.58 & -0.56 & -0.56 & -0.61 & -0.54 & -0.49 & \\
\hline & MNE & 0.63 & 0.65 & 0.65 & 0.63 & 0.64 & 0.63 & 0.63 & 0.66 & 0.62 & 0.59 & \\
\hline \multirow[t]{6}{*}{$\mathrm{NO}_{2}(\mathrm{ppb})$} & OBS & 23.33 & 21.26 & 19.83 & 18.11 & 16.34 & 16.5 & 19.74 & 24.82 & 27.41 & 31.41 & \\
\hline & PRE & 10.11 & 8.87 & 8.51 & 8.74 & 8.12 & 8.77 & 10.45 & 11.85 & 13.45 & 13.87 & \\
\hline & MFB & -0.83 & -0.88 & -0.86 & -0.79 & -0.79 & -0.73 & -0.71 & -0.76 & -0.7 & -0.77 & \\
\hline & MFE & 0.94 & 0.99 & 0.99 & 0.95 & 0.95 & 0.91 & 0.89 & 0.91 & 0.85 & 0.87 & \\
\hline & MNB & -0.45 & -0.48 & -0.46 & -0.4 & -0.4 & -0.35 & -0.35 & -0.39 & -0.37 & -0.44 & \\
\hline & MNE & 0.65 & 0.67 & 0.68 & 0.68 & 0.68 & 0.67 & 0.66 & 0.65 & 0.62 & 0.61 & \\
\hline \multirow[t]{6}{*}{$\mathrm{SO}_{2}(\mathrm{ppb})$} & OBS & 19.1 & 15.8 & 15.25 & 12.93 & 12.32 & 12.96 & 13.24 & 15.53 & 21.74 & 27.88 & \\
\hline & PRE & 11.64 & 8.87 & 8.31 & 8.61 & 7.09 & 8.88 & 11.94 & 14.25 & 17.91 & 23.32 & \\
\hline & MFB & -0.61 & -0.66 & -0.68 & -0.59 & -0.73 & -0.56 & -0.39 & -0.29 & -0.31 & -0.32 & \\
\hline & MFE & 0.89 & 0.9 & 0.91 & 0.89 & 0.98 & 0.89 & 0.84 & 0.78 & 0.82 & 0.83 & \\
\hline & MNB & -0.14 & -0.23 & -0.23 & -0.11 & -0.22 & -0.08 & 0.23 & 0.25 & 0.29 & 0.31 & \\
\hline & MNE & 0.79 & 0.74 & 0.76 & 0.8 & 0.81 & 0.82 & 1 & 0.95 & 1.01 & 1.03 & \\
\hline
\end{tabular}

predictions are matched at individual station level and the averaged observations and predictions are used to represent the concentrations for the city. Some cities, such as Beijing, exhibit substantial diurnal variations, especially in summer; others, such as Lhasa, exhibit small diurnal variations. Overall, the model successfully reproduces the monthly average diurnal variation in most cities, even though model performance among cities in the same region can be quite differ- ent. For example, in NE, the monthly averaged predictions agree well with observations in Shenyang and Changchun but are higher in Dalian, a coastal city, in summer months. In NCP, the model predicts well $\mathrm{O}_{3}$ concentrations with slight overprediction at a few cities, especially in the summer months, which agrees with the better hourly $\mathrm{O}_{3}$ model performance shown in Tables 3 and 4. In YRD, the monthly diurnal variations of $\mathrm{O}_{3}$ are also well predicted. Obvious un- 
Table 4. Model performance on $\mathrm{O}_{3}-1 \mathrm{~h}, \mathrm{O}_{3}-8 \mathrm{~h}, \mathrm{PM}_{2.5}, \mathrm{PM}_{10}, \mathrm{CO}, \mathrm{NO}_{2}$, and $\mathrm{SO}_{2}$ in different regions during March to December 2013. The values that do not meet the criteria are denoted in bold.

\begin{tabular}{|c|c|c|c|c|c|c|c|c|c|}
\hline & & NCP & YRD & PRD & SCB & $\mathrm{NE}$ & CEN & NW & Other \\
\hline \multirow[t]{6}{*}{$\mathrm{O}_{3}-1 \mathrm{~h}$} & OBS & 65.18 & 63.84 & 65.7 & 67.85 & 53.37 & 63.1 & 54.5 & 54.21 \\
\hline & PRE & 65.84 & 59.02 & 56.6 & 71.36 & 57.9 & 62.79 & 60.5 & 55.37 \\
\hline & MFB & 0.03 & -0.07 & -0.13 & 0.08 & 0.09 & 0.03 & 0.14 & 0.05 \\
\hline & MFE & 0.27 & 0.27 & 0.3 & 0.31 & 0.24 & 0.31 & 0.28 & 0.28 \\
\hline & MNB & 0.1 & -0.01 & -0.06 & 0.18 & 0.14 & 0.12 & 0.22 & 0.13 \\
\hline & MNE & 0.3 & 0.26 & 0.29 & 0.36 & 0.27 & 0.34 & 0.33 & 0.3 \\
\hline \multirow[t]{6}{*}{$\mathrm{O}_{3}-8 \mathrm{~h}$} & OBS & 53.38 & 52.96 & 51.25 & 53.48 & 46.73 & 49.88 & 44.26 & 45 \\
\hline & PRE & 57.51 & 51.72 & 46.13 & 59.04 & 52.18 & 54.33 & 52.67 & 49.94 \\
\hline & MFB & 0.06 & -0.03 & -0.11 & 0.1 & 0.1 & 0.08 & 0.18 & 0.1 \\
\hline & MFE & 0.26 & 0.26 & 0.26 & 0.26 & 0.23 & 0.26 & 0.28 & 0.24 \\
\hline & MNB & 0.13 & 0.02 & -0.06 & 0.17 & 0.15 & 0.15 & 0.25 & 0.16 \\
\hline & MNE & 0.3 & 0.26 & 0.24 & 0.3 & 0.26 & 0.3 & 0.33 & 0.28 \\
\hline \multirow{6}{*}{$\mathrm{PM}_{2.5}\left(\mu \mathrm{g} \mathrm{m}^{-3}\right)$} & OBS & 90.85 & 65.55 & 49.28 & 65.61 & 60.93 & 77.74 & 70.13 & 42.7 \\
\hline & PRE & 65.5 & 55.55 & 29.19 & 78.83 & 48.57 & 74.95 & 33.84 & 33.55 \\
\hline & MFB & -0.33 & -0.27 & -0.56 & 0.05 & -0.26 & -0.16 & -0.75 & -0.53 \\
\hline & MFE & 0.64 & 0.57 & 0.68 & 0.57 & 0.62 & 0.57 & 0.88 & 0.77 \\
\hline & MNB & -0.01 & -0.04 & -0.33 & 0.47 & 0.03 & 0.15 & -0.39 & -0.2 \\
\hline & MNE & 0.65 & 0.54 & 0.52 & 0.84 & 0.63 & 0.66 & 0.65 & 0.63 \\
\hline \multirow[t]{6}{*}{$\mathrm{PM}_{10}\left(\mu \mathrm{g} \mathrm{m}^{-3}\right)$} & OBS & 164.80 & 104.94 & 69.85 & 104.79 & 99.08 & 122.64 & 143.95 & 68.67 \\
\hline & PRE & 73.69 & 63.47 & 34.20 & 86.70 & 52.80 & 80.44 & 44.25 & 35.63 \\
\hline & MFB & -0.71 & -0.55 & -0.69 & -0.25 & -0.62 & -0.49 & -0.98 & -0.76 \\
\hline & MFE & 0.84 & 0.70 & 0.77 & 0.62 & 0.78 & 0.70 & 1.05 & 0.87 \\
\hline & MNB & -0.37 & -0.30 & -0.43 & 0.07 & -0.32 & -0.20 & -0.56 & -0.42 \\
\hline & MNE & 0.63 & 0.54 & 0.55 & 0.68 & 0.60 & 0.60 & 0.69 & 0.62 \\
\hline \multirow[t]{6}{*}{$\mathrm{CO}$} & OBS & 1.22 & 0.8 & 0.81 & 0.82 & 0.79 & 1.11 & 1.13 & 0.75 \\
\hline & PRE & 0.37 & 0.29 & 0.22 & 0.41 & 0.25 & 0.4 & 0.23 & 0.22 \\
\hline & MFB & -0.89 & -0.86 & -1.11 & -0.62 & -0.93 & -0.87 & -1.21 & -1.04 \\
\hline & MFE & 0.95 & 0.9 & 1.12 & 0.71 & 0.96 & 0.93 & 1.22 & 1.07 \\
\hline & MNB & -0.54 & -0.55 & -0.69 & -0.39 & -0.58 & -0.52 & -0.72 & -0.63 \\
\hline & MNE & 0.63 & 0.6 & 0.7 & 0.52 & 0.63 & 0.62 & 0.74 & 0.68 \\
\hline \multirow[t]{6}{*}{$\mathrm{NO}_{2}$} & OBS & 24.28 & 21.42 & 23.12 & 21.2 & 21.09 & 21.01 & 22.23 & 16.2 \\
\hline & PRE & 11.26 & 11.77 & 10.71 & 12.53 & 6.37 & 12.03 & 8.4 & 4.29 \\
\hline & MFB & -0.72 & -0.65 & -0.7 & -0.56 & -1.09 & -0.62 & -0.95 & -1.24 \\
\hline & MFE & 0.85 & 0.83 & 0.83 & 0.78 & 1.15 & 0.83 & 1.05 & 1.28 \\
\hline & MNB & -0.39 & -0.31 & -0.39 & -0.24 & -0.61 & -0.27 & -0.52 & -0.7 \\
\hline & MNE & 0.62 & 0.63 & 0.6 & 0.62 & 0.73 & 0.66 & 0.69 & 0.75 \\
\hline \multirow[t]{6}{*}{$\mathrm{SO}_{2}$} & OBS & 22.31 & 14.07 & 10.41 & 12.83 & 21.06 & 17.26 & 16.66 & 11.81 \\
\hline & PRE & 12.24 & 8.66 & 8.07 & 25.77 & 5.13 & 18.55 & 11.58 & 10.28 \\
\hline & MFB & -0.57 & -0.62 & -0.45 & 0.34 & -1.14 & -0.24 & -0.6 & -0.63 \\
\hline & MFE & 0.8 & 0.87 & 0.77 & 0.73 & 1.21 & 0.8 & 0.95 & 1 \\
\hline & MNB & -0.21 & -0.22 & -0.1 & 1.5 & -0.61 & 0.46 & -0.07 & -0.02 \\
\hline & MNE & 0.66 & 0.71 & 0.69 & 1.78 & 0.76 & 1.13 & 0.86 & 0.94 \\
\hline
\end{tabular}

derprediction of summer peak $\mathrm{O}_{3}$ at Zhoushan and Wenzhou are likely caused by underestimation of emissions in these port cities, although uncertainty in meteorology might also play a role. At PRD, $\mathrm{O}_{3}$ is slightly underestimated in Guangzhou and Shenzhen for summer and fall months but well estimated in Zhuhai. In all three cities in the PRD re- gion, $\mathrm{O}_{3}$ concentrations are higher in the spring and fall months, and the model correctly captures this trend. In SCB, the model correctly predicts the higher spring $\mathrm{O}_{3}$ concentrations in Chengdu but overpredicts spring $\mathrm{O}_{3}$ concentrations in Chongqing. Summer $\mathrm{O}_{3}$ concentrations are well predicted at both cities. For CEN, $\mathrm{O}_{3}$ predictions are higher than ob- 


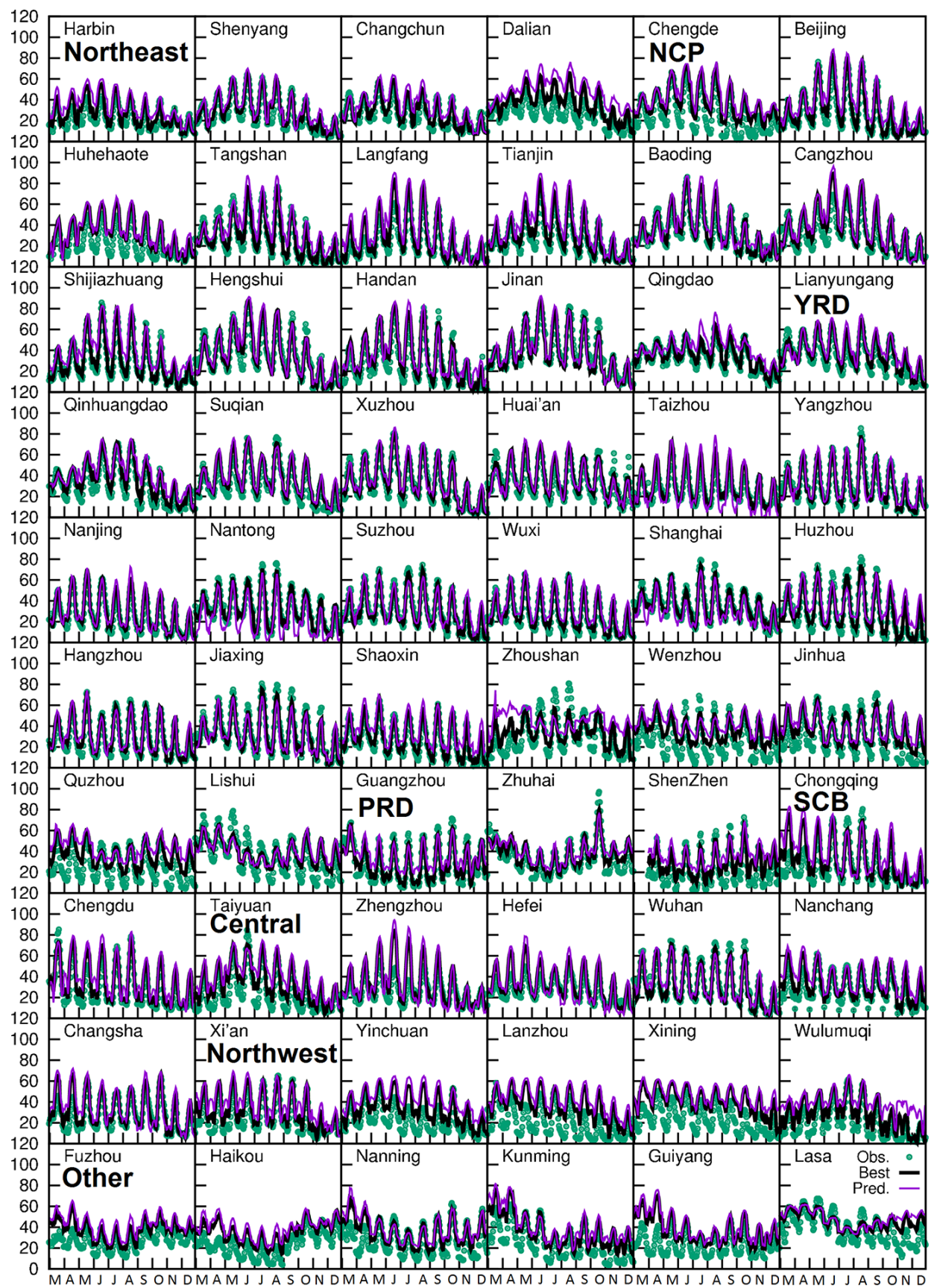

Figure 2. Comparison of monthly averaged diurnal variations of $\mathrm{O}_{3}$ concentrations from March to December 2013. Pred. are the values predicted at the grid cell each city center located while Best are the values predicted closest to the observations within $3 \times 3$ grid cell regions that surround the observation. Units are ppb.

servations in Zhengzhou and Hefei but agree well with observations in other cities. In NW, the observed $\mathrm{O}_{3}$ concentrations are much lower and are generally overpredicted all year except for Xi' an and Wulumuqi with good performance in summer.

Figure 3 shows the comparison of predicted and observed monthly averaged $\mathrm{O}_{3}-1 \mathrm{~h}$ and $\mathrm{O}_{3}-8 \mathrm{~h}$ concentrations at typi- cal cities of major regions in China: Beijing for NCP, Shanghai for YRD, Guangzhou for PRD, Xi' an for NW, Shenyang for NE, and Chongqing for SCB. In Beijing, the monthly variations of both $\mathrm{O}_{3}-1 \mathrm{~h}$ and $\mathrm{O}_{3}-8 \mathrm{~h}$, low in winter months and high in summer months, are well captured by the model. The model slightly overpredicts $\mathrm{O}_{3}$ concentrations from June to December except for August. In Shanghai, both $\mathrm{O}_{3}-1 \mathrm{~h}$ and 

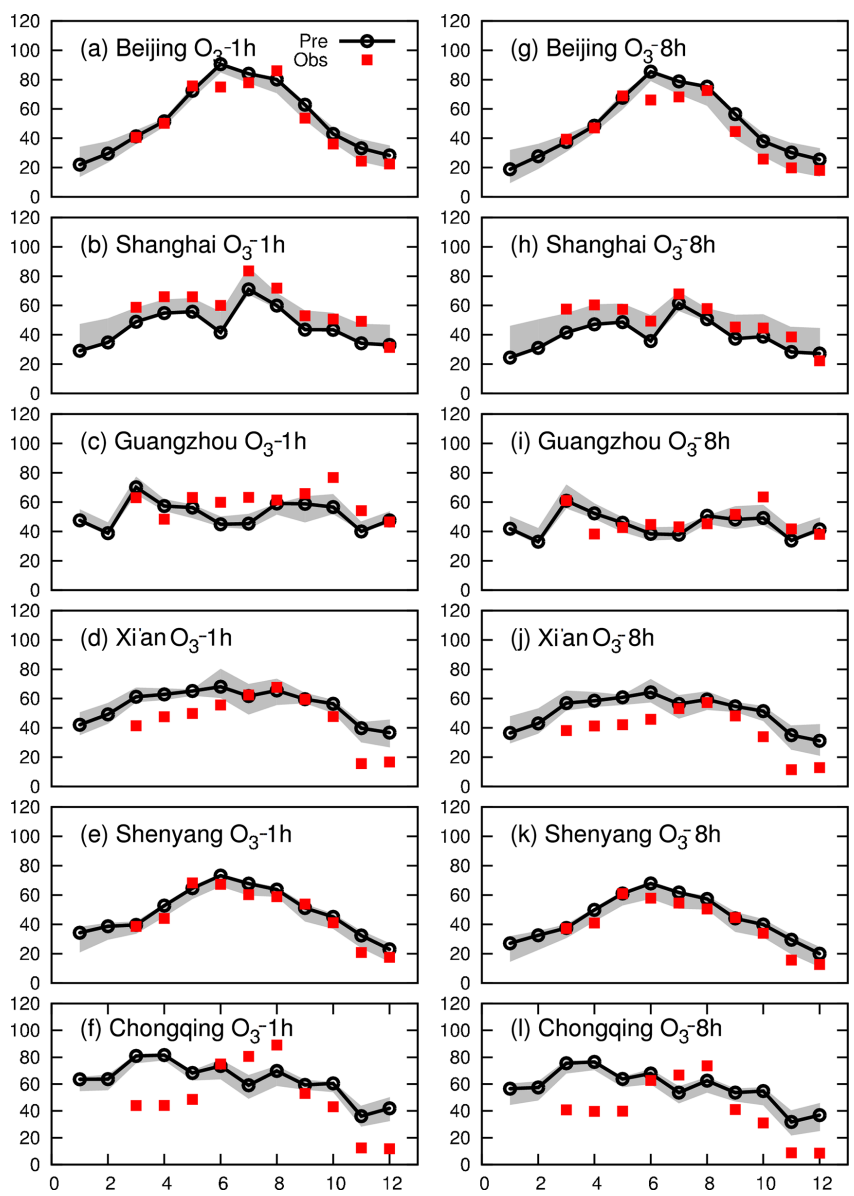

Figure 3. Comparison of predicted and observed $\mathrm{O}_{3}-1 \mathrm{~h}$ and $\mathrm{O}_{3}-8 \mathrm{~h}$ concentrations at Beijing, Shanghai, Guangzhou, Xi'an, Shenyang, and Chongqing. Grey areas represent ranges in model predictions within $3 \times 3$ grid cells surrounding the observation. Units are ppb.

$\mathrm{O}_{3}-8 \mathrm{~h}$ are underestimated by $5-10 \mathrm{ppb}$, but all observations are within the range of concentrations in the $3 \times 3$ grid cells surrounding the city center of Shanghai. In Guangzhou, $\mathrm{O}_{3}$ concentrations vary slightly over months. $\mathrm{O}_{3}-1 \mathrm{~h}$ is underpredicted especially in summer and fall months. $\mathrm{O}_{3}-8 \mathrm{~h}$ predictions are closer to the observations. In Xi' an, the model well predicts the $\mathrm{O}_{3}-1 \mathrm{~h}$ and $\mathrm{O}_{3}-8 \mathrm{~h}$ concentrations in July, August, and September while it overpredicts all other months by up to $20 \mathrm{ppb}$. In Shenyang, the trend of $\mathrm{O}_{3}-1 \mathrm{~h}$ and $\mathrm{O}_{3}-8 \mathrm{~h}$ are well reproduced with less than $5 \mathrm{ppb}$ differences for all the months. In Chongqing, overprediction occurs in spring, fall, and winter while underprediction occurs in summer.

\subsection{2 $\quad \mathbf{P M}_{2.5}$ model performance}

$\mathrm{PM}_{2.5}$ model performance in different months and regions is also illustrated in Tables 3 and 4 respectively. The model performance statistics of MFB and MFE of hourly $\mathrm{PM}_{2.5}$ concentrations meet the US EPA criteria in all months. Negative MFB is found in all months, indicating the model underpre- dicts the $\mathrm{PM}_{2.5}$ concentrations. Model performance is better in March, September, November, and December, with MFB less than 0.3. The bias is relatively larger in April, May, June, July, and October, with MFB over 0.4 . PM $_{10}$ is largely underestimated and is very likely due to underestimation of dust emissions from both natural sources as well as human activities.

Model performance of $\mathrm{PM}_{2.5}$ in different regions is also different. The model significantly underpredicts $\mathrm{PM}_{2.5}$ in the NW and the other (mostly southwestern cities) regions. Especially in the NW region, MFB value is -0.75 and MFE value is $0.88 . \mathrm{PM}_{2.5}$ in all the other regions meets the performance criteria. Although most regions meet the model performance criteria in this study, underprediction of $\mathrm{PM}_{2.5}$ concentrations is found in all regions (except SCB), as indicated by the large negative MFB values. $\mathrm{PM}_{10}$ has a similar performance in various regions.

Figure 4 illustrates the comparison of predicted and observed monthly averaged $\mathrm{PM}_{2.5}$ concentrations for all the 60 cities. In NE, the predictions agree well with observations in summer months. Concentrations in fall and winter months are underpredicted, except for Dalian, where all the values are well reproduced. In NCP, the annual trends at most cities are well captured. The model trends to underpredict spring and summer concentrations and overpredict December concentrations. The coastal city, Qingdao, is unique with underprediction in summer and good estimation in other months. In YRD, the model well produces $\mathrm{PM}_{2.5}$ for all the months at most sites except in coastal cities (Zhoushan and Wenzhou) and mountainous cities (Quzhou and Lishui). In SCB, the model underestimates concentrations in the winter months in Chongqing but estimates well the concentrations in Chengdu except for March and April. In CEN, the seasonal trend is well captured in all cities but most cities show overpredicted concentrations in December. In NE, $\mathrm{PM}_{2.5}$ is uniformly underpredicted. For other regions, predictions agree with observations at the coastal cities (Fuzhou and Haikou) but concentrations in Lhasa are largely underpredicted. The values closest to the observations in the $3 \times 3$ surrounding grid cells are similar to the predictions at city centers for most months with clear differences in October, November, and December at several cities. It indicates the higher contributions of primary PM, which has steeper concentration gradients than secondary PM, in winter months than in summer months.

Generally, the WRF/CMAQ modeling system with MEIC inventory reproduces well the $\mathrm{O}_{3}$ and $\mathrm{PM}_{2.5}$ concentrations in most regions for most months. Overprediction of $\mathrm{O}_{3}$ occurs at low concentrations in winter while underprediction of $\mathrm{PM}_{2.5}$ happens at low concentration range in summer and in cities in the NW region. The model performance on $\mathrm{CO}$, $\mathrm{NO}_{2}$, and $\mathrm{SO}_{2}$ is also calculated and listed in Tables 3 and 4. There are no performance criteria for these pollutants, but the model performance is in the same ranges as compared to other studies in other countries/regions (J. Tao et al., 2014). The model performance at different regions differs due to the 


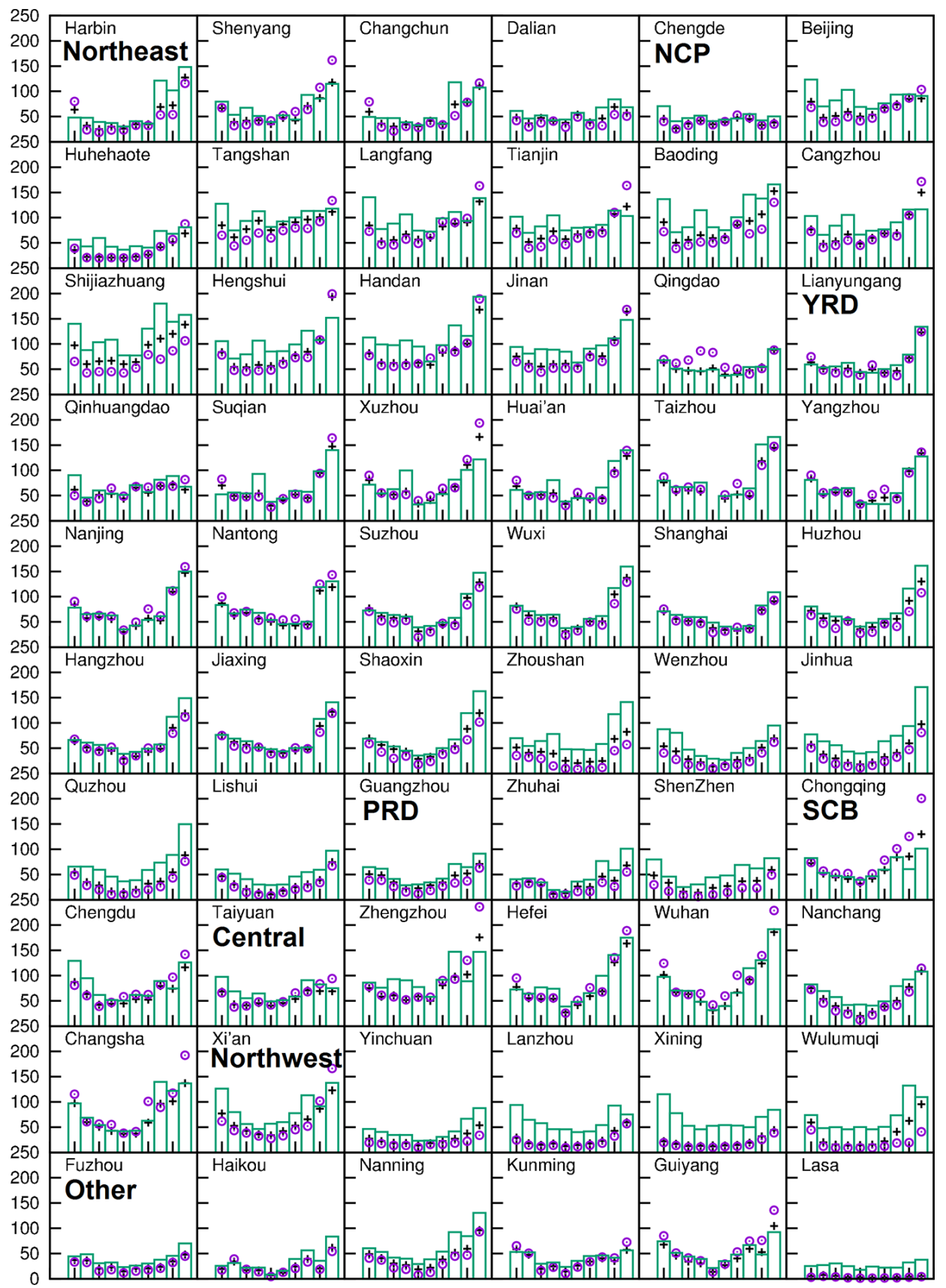

Figure 4. Comparison of predicted (in column) and observed (in circle) monthly averaged $\mathrm{PM}_{2.5}$ concentrations for March to December 2013. The "best" symbols (in "+") represent predictions closest to the hourly observations within a $3 \times 3$ grid cell region with the grid cell where the monitoring sites are located at the center. Units are $\mu \mathrm{g} \mathrm{m}^{-3}$.

differences in emission, topography, and meteorological conditions. The performance on these species can be used as indicator for emission uncertainties. The possible uncertainties are discussed in Sect. 4.

\subsection{Seasonal variations and regional distribution of $\mathrm{O}_{3}$ and $\mathbf{P M}_{2.5}$}

Figure 5 shows the predicted regional distribution of seasonal averaged $\mathrm{O}_{3}-1 \mathrm{~h}$ and $\mathrm{O}_{3}-8 \mathrm{~h}$. In spring, highest $\mathrm{O}_{3}$ $1 \mathrm{~h}$ concentration $(\sim 100 \mathrm{ppb})$ occurs in South Asia due to higher temperature, solar radiation, and a significant amount of emissions from open biomass burning activities (Kondo 


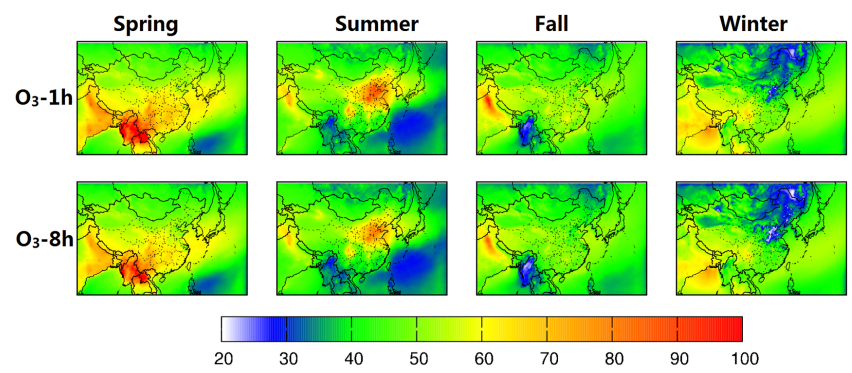

Figure 5. Seasonal variations of predicted regional distribution of $\mathrm{O}_{3}-1 \mathrm{~h}$ and $\mathrm{O}_{3}-8 \mathrm{~h}$. Units are ppb.

et al., 2004). Southern China has higher concentrations $(\sim 70 \mathrm{ppb})$ than northern China $(\sim 50 \mathrm{ppb})$. However, in summer, NCP has the highest concentration of $80 \mathrm{ppb}$ while southern China (and other regions) has lower concentrations of 50-60 ppb. In fall, most of the regions in China have $\mathrm{O}_{3}$ $1 \mathrm{~h}$ concentrations of 50-60 ppb. In winter, NE China and $\mathrm{NCP}$ have $\mathrm{O}_{3}-1 \mathrm{~h}$ concentrations lower than $30 \mathrm{ppb}$ while southern China has the concentrations of $40-50 \mathrm{ppb}$. In addition to NCP in the summer, SCB is also another hot spot for ozone with high summertime and wintertime $\mathrm{O}_{3}-1 \mathrm{~h}$ of $\sim 100 \mathrm{ppb}$ and $60-70 \mathrm{ppb}$ respectively. $\mathrm{O}_{3}-8 \mathrm{~h}$ has similar spatial distribution patterns as $\mathrm{O}_{3}-1 \mathrm{~h}$ for all seasons with lower concentrations (by 5-10 ppb).

Figure 6 shows the spatial distribution of seasonal averaged $\mathrm{PM}_{2.5}$ concentrations together with the averaged wind vectors as the regional distribution of $\mathrm{PM}_{2.5}$ is significantly influenced by wind patterns. In spring, the $\mathrm{PM}_{2.5}$ concentrations in China reach approximately $50-70 \mu \mathrm{g} \mathrm{m}^{-3}$ in northern, eastern, and southern China except coastal provinces of Zhejiang, Fujian, and Guangdong. It is evident that the high concentrations are related to low wind speed. In summer, the areas with high $\mathrm{PM}_{2.5}$ concentrations of $\sim 50 \mu \mathrm{g} \mathrm{m}^{-3}$ are limited to NCP and SCB while all other regions have concentrations of $<30 \mu \mathrm{g} \mathrm{m}^{-3}$. Emissions brought to the NCP by the southerly wind, blockage of dispersion due to mountain ranges to the north and west, and SOA formed due to strong solar radiation are contributing factors for higher summer $\mathrm{PM}_{2.5}$ in NCP. In fall, the high concentration regions are similar to those in spring but with higher concentrations of up to $100 \mu \mathrm{g} \mathrm{m}^{-3}$ in NCP, YRD, CEN, and SCB. In winter, high $\mathrm{PM}_{2.5}$ concentrations are located in the NE, NCP, YRD, CEN, and SCB regions. Seasonal average concentrations of more than $200 \mu \mathrm{g} \mathrm{m}^{-3}$ occur in large portions of NCP, CEN, and SCB due to low wind speed and mixing height. Strong gradient exists between the high concentration regions and surrounding areas where wind is more lenient to pollutant dispersion.

Figure 7 shows the spatial distribution of seasonal averaged $\mathrm{PM}_{2.5}$ components. All components show clear seasonal variations. For secondary inorganic components and anthropogenic primary components (EC and POA), concen-

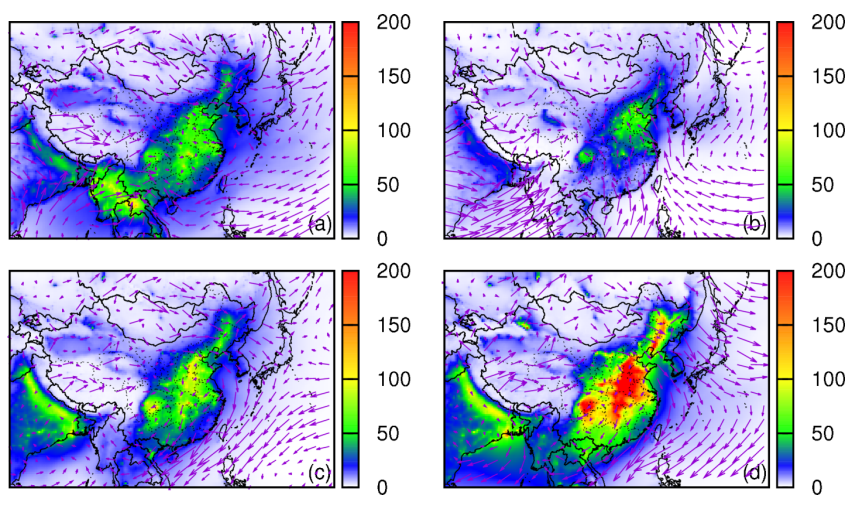

Figure 6. Seasonal variation of predicted $\mathrm{PM}_{2.5}$ and wind vectors: (a) spring, (b) summer, (c) fall, and (d) winter. Units are $\mu \mathrm{g} \mathrm{m}^{-3}$.

trations are usually highest in winter and lowest in summer. Spring and fall concentrations are similar with slightly higher concentrations in fall. For EC and POA, this seasonal variation is largely driven by large increase in the emissions from residential sources in winter, as well as reduced ventilation that is often associated with winter stagnant conditions. For secondary inorganic components, gas phase formation rate of $\mathrm{HNO}_{3}$ and $\mathrm{H}_{2} \mathrm{SO}_{4}$ decreases as temperature and solar radiation intensity decreases in fall and winter, leading to a decrease in their formation from the homogeneous pathways. However, the amount of secondary $\mathrm{NO}_{3}^{-}$and $\mathrm{SO}_{4}^{2-}$ from surface heterogeneous reactions of $\mathrm{SO}_{2}$ and $\mathrm{NO}_{2}$ increases as their emissions increase, and more particle surface area becomes available due to an increase in primary PM concentrations. In addition, ammonium nitrate is preferentially partitioned into the particle phase under colder temperatures (Aw and Kleeman, 2003). In most regions with high concentrations, wintertime $\mathrm{NO}_{3}^{-}$concentrations are 150-200\% higher than annual average concentrations, while $\mathrm{SO}_{4}^{2-}$ and $\mathrm{NH}_{4}^{+}$concentrations are approximately $100-150 \%$ higher (see Fig. 8). POA concentrations in winter are also approximately $100-150 \%$ higher in winter than the annual average, especially in northern part of China where residential heating is a significant source of $\mathrm{PM}_{2.5}$ emissions. In provinces in southern China with warm temperatures, winter POA is not significantly deviated from the annual mean (see Fig. 8). Maximum concentrations of $\mathrm{NO}_{3}^{-}$and $\mathrm{SO}_{4}^{2-}$ increase to beyond $50 \mu \mathrm{g} \mathrm{m}^{-3}$ and those of $\mathrm{NH}_{4}^{+}$to as high as $40 \mu \mathrm{g} \mathrm{m}^{-3}$ in portions of NCP, CEN, YRD, and SCB. This suggests that in large areas, secondary inorganic PM is the most significant contributor to elevated wintertime $\mathrm{PM}_{2.5}$ concentrations. $\mathrm{EC}$ has limited spatial distribution since it is only directly emitted. Highest EC concentrations are in NCP, CEN and SCB. The EC concentrations are $10-15 \mu \mathrm{g} \mathrm{m}^{-3}$ in winter but lower than $5 \mu \mathrm{g} \mathrm{m}^{-3}$ in other seasons. POA concentrations are highly seasonally dependent with the highest concentrations of $\sim 30 \mu \mathrm{g} \mathrm{m}^{-3}$ in NCP, CEN, SCB, and NE occurring in winter. 

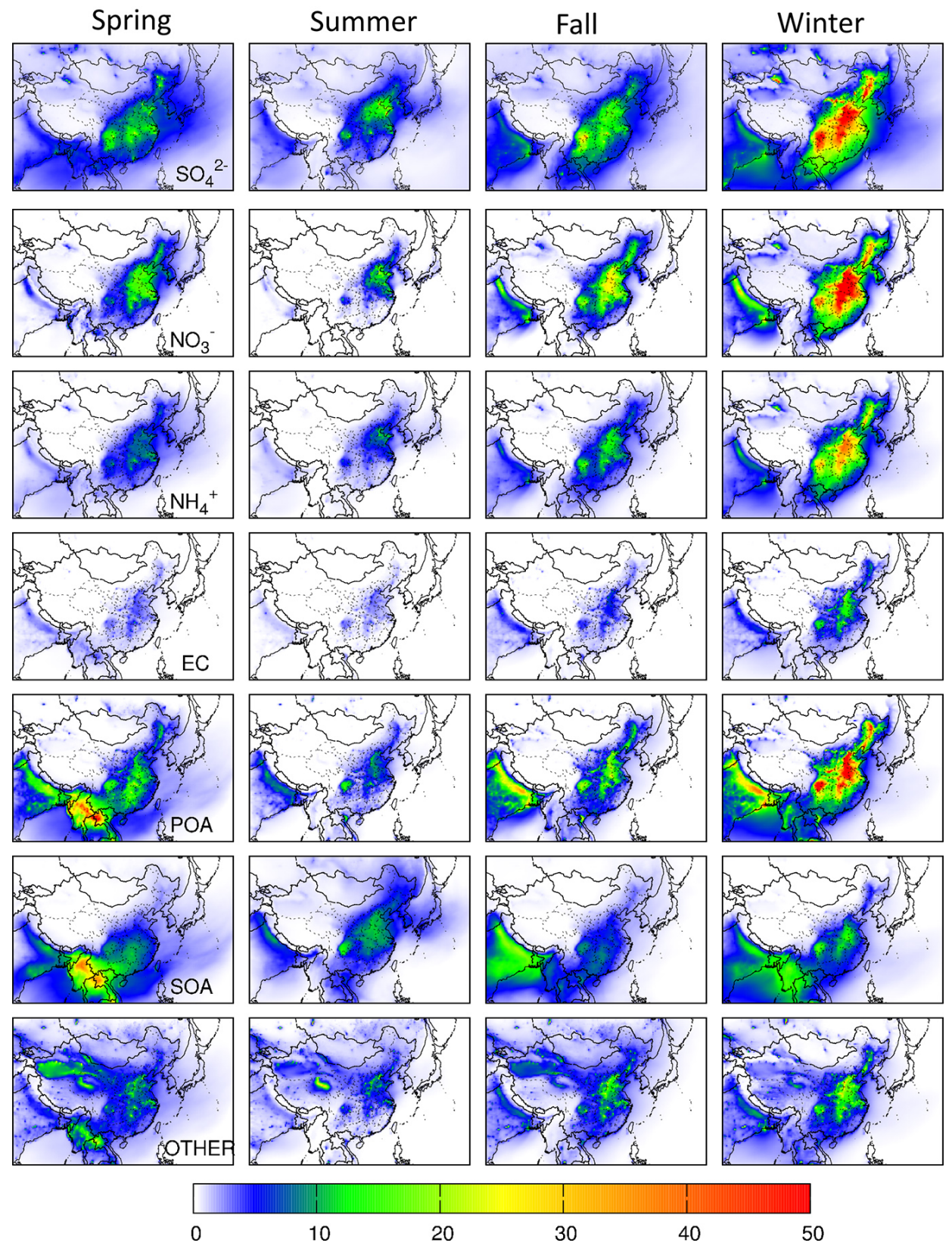

Figure 7. Seasonal variations of predicted $\mathrm{PM}_{2.5}$ components. Units are $\mu \mathrm{g} \mathrm{m}{ }^{-3}$.

SOA shows different seasonal variations from the secondary inorganic aerosol and anthropogenic primary PM components. In CEN and eastern China, higher seasonal average SOA concentrations of $10-15 \mu \mathrm{g} \mathrm{m}^{-3}$ occur in summer and winter, while in southern China similar levels of SOA occur in spring. The spring and summer high SOA concentrations are dominantly formed from biogenic isoprene emissions but winter SOA is mainly formed from semi-volatile oxidation products of anthropogenic aromatic compounds. Details of SOA formation and composition will be discussed in a separate paper. "Other" components are primary $\mathrm{PM}_{2.5}$ mostly from dust. The concentrations are high in spring, fall, and winter. In summary, secondary components have more boarder distribution than primary components. $\mathrm{SO}_{4}^{2-}, \mathrm{NO}_{3}^{-}$, $\mathrm{NH}_{4}^{+}$, and POA are the most important aerosol components based on their absolute concentrations.

It should be noted that the simulated spatiotemporal distribution of $\mathrm{PM}_{2.5}$ and its chemical composition is affected by the temporally and spatially variant biases of $\mathrm{PM}_{2.5}$. In summer $\mathrm{PM}_{2.5}$ is more underpredicted when the concentrations are lower; therefore the actual seasonal variation of $\mathrm{PM}_{2.5}$ is likely weaker than the predictions. $\mathrm{PM}_{2.5}$ is more 

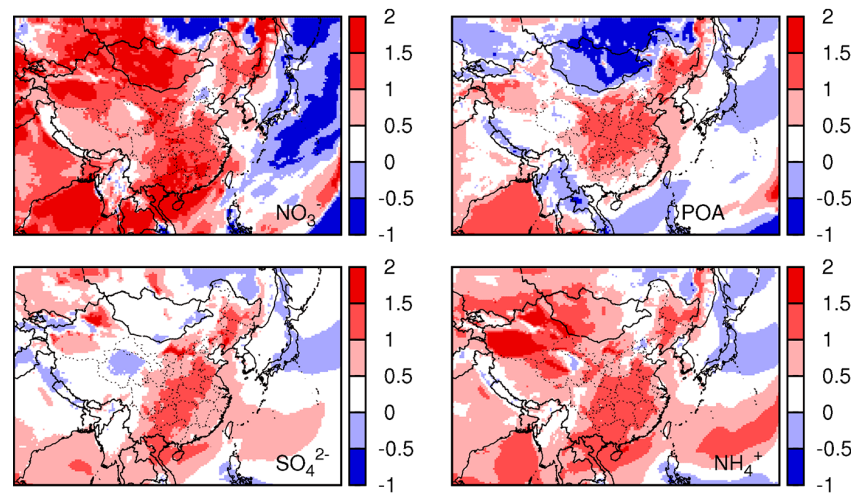

Figure 8. Deviation of winter nitrate $\left(\mathrm{NO}_{3}^{-}\right)$, sulfate $\left(\mathrm{SO}_{4}^{2-}\right)$, ammonium ion $\left(\mathrm{NH}_{4}^{+}\right)$, and primary organic aerosol (POA) from annual average, as calculated by $(W-A) / A$, where $W$ and $A$ are winter and annual concentrations respectively.

underpredicted in NW where the concentrations are lower; therefore the actual spatial difference between NW and eastern China regions (e.g., NCP, YRD) is also likely weaker. The spatiotemporal distribution of $\mathrm{PM}_{2.5}$ chemical composition is expected to be affected similarly but this needs to be confirmed through detailed $\mathrm{PM}_{2.5}$ composition observations. The biases of $\mathrm{O}_{3}$ exhibit much less variation temporally and spatially, so the predicted spatiotemporal distribution of $\mathrm{O}_{3}$ is more accurate than $\mathrm{PM}_{2.5}$.

\subsection{Temporal variation of $\mathbf{P M}_{2.5}$ components in representative cities}

Temporal variations of $\mathrm{PM}_{2.5}$ components are also shown at typical cities in different regions as in Fig. 9. The total $\mathrm{PM}_{2.5}$ concentrations in Beijing are high in winter and low in summer with the peak of $\sim 150 \mu \mathrm{g} \mathrm{m}^{-3}$ in January. EC contributions are $\sim 5-10 \%$ in winter but less than $5 \%$ in other seasons. POA has a similar pattern as EC but contributions can be $\sim 35 \%$ in winter and $\sim 20 \%$ in summer. SOA contributions are high in summer with the peak of $\sim 30 \%$ in August and very low in winter. $\mathrm{SO}_{4}^{2-}$ and $\mathrm{NO}_{3}^{-}$are the top two largest contributors with comparable contributions all the time. $\mathrm{NH}_{4}^{+}$can be as high as $\sim 20 \%$ in January and only $\sim 10 \%$ in summer. Other components ("other", mostly oxides of crustal elements and other trace metals) contribute up to $15 \%$ in some months. In Shanghai, the monthly averaged concentrations are highest in winter and decrease gradually from spring to fall. Five out of the 12 months are over the Chinese Ambient Air Quality Standards (CAAQS) Grade II standard for $24 \mathrm{~h}$ average $\mathrm{PM}_{2.5}\left(75 \mu \mathrm{g} \mathrm{m}^{-3}\right.$, simply Grade II standard hereafter). EC and POA have similar pattern with a total contribution of $20 \%$ in most months. $\mathrm{SO}_{4}^{2-}, \mathrm{NO}_{3}^{-}$, and $\mathrm{NH}_{4}^{+}$contribute to more than $70 \%$ from November to June and less than $50 \%$ in other months, while the contribution of SOA increases significantly to as much as $40 \%$ in the sum- mer months. The relative contributions of the "other" components are about 2 times of those in Beijing (15\% to $30 \%$ ). In Guangzhou, the $\mathrm{PM}_{2.5}$ concentrations are lower than Beijing and Shanghai. Predicted $\mathrm{PM}_{2.5}$ concentrations are all within the Grade II standard in China. Although the contribution of $\mathrm{SOA}$ is higher, $\mathrm{SO}_{4}^{2-}, \mathrm{NO}_{3}^{-}$, and $\mathrm{NH}_{4}^{+}$are still the major components with more than $60 \%$ contribution all over the year.

In Xi' an, the largest city in NW, the differences in $\mathrm{PM}_{2.5}$ at winter and other months are significant. In winter, the total $\mathrm{PM}_{2.5}$ concentrations are $150-180 \mu \mathrm{g} \mathrm{m}^{-3}$ with $\mathrm{POA}, \mathrm{SO}_{4}^{2-}$, $\mathrm{NO}_{3}^{-}$, and $\mathrm{NH}_{4}^{+}$as major components. In Shenyang, a NE city, the $\mathrm{PM}_{2.5}$ concentrations are $\sim 250 \mu \mathrm{g} \mathrm{m}^{-3}$ in January followed by $\sim 200 \mu \mathrm{g} \mathrm{m}^{-3}$ in February and $\sim 150 \mu \mathrm{g} \mathrm{m}^{-3}$ in December. The extremely high concentrations are related to winter residential heating or uncontrolled open biomass (such as straw) burning as can be indicated by the elevated emissions from residential sources. For other seasons, contributions of other components are much lower but the contribution of SOA increases to more than $20 \%\left(\sim 10 \mu \mathrm{g} \mathrm{m}^{-3}\right)$ in June, likely due to increased biogenic emissions in the densely forested regions in the NE. In Chongqing, located in $\mathrm{SCB}$, the monthly average reaches as high as $230 \mu \mathrm{g} \mathrm{m}^{-3}$ in January due to increased atmospheric stability. Spring, summer, and fall months have much lower $\mathrm{PM}_{2.5}$ concentrations especially for July, when the $\mathrm{PM}_{2.5}$ is lower than $50 \mu \mathrm{g} \mathrm{m}^{-3}$.

One of the questions that remain unclear is whether secondary PM formation is enhanced during the high pollution days or high pollution events are simply caused by enhanced emissions and reduced dilution due to stagnant conditions. As an attempt to address this question, Fig. 10 shows the comparison of relative contributions of $\mathrm{PM}_{2.5}$ components in episode days ( $>=$ the Grade II standard of $75 \mu \mathrm{g} \mathrm{m}^{-3}$ ) and non-episode days. In Guangzhou, there are no episode days predicted, thus only Beijing, Shanghai, Xi' an, Shenyang, and Chongqing are included in Fig. 10. In all cities, the minimum episode-day averaged concentration occurs in summer while the maximum concentration occurs in winter. In most cities and in most seasons, episode days have larger contributions of secondary components $\left(\mathrm{SOA}, \mathrm{SO}_{4}^{2-}, \mathrm{NO}_{3}^{-}\right.$, and $\mathrm{NH}_{4}^{+}$; $69.8 \%$ on episode days vs. $59.9 \%$ on non-episode days) and lower contributions of primary components (EC, POA, and other; $30.2 \%$ on episode days vs. $40.1 \%$ on non-episode days). Some cities show drastic differences in secondary PM contributions between episode and non-episode days. For example, contribution of secondary PM in Xi' an increases from $40 \%$ on non-episode days to more than $60 \%$ on episode days in winter. Other cities, such as Chongqing, show less difference in the relative contributions of secondary PM between episode and non-episode days. While most of the secondary $\mathrm{PM}$ increase is due to enhanced formation of secondary inorganic components, the contribution of SOA to total PM is significantly higher than that on non-episode days in summer Beijing. This suggests that enhanced SOA formation could 

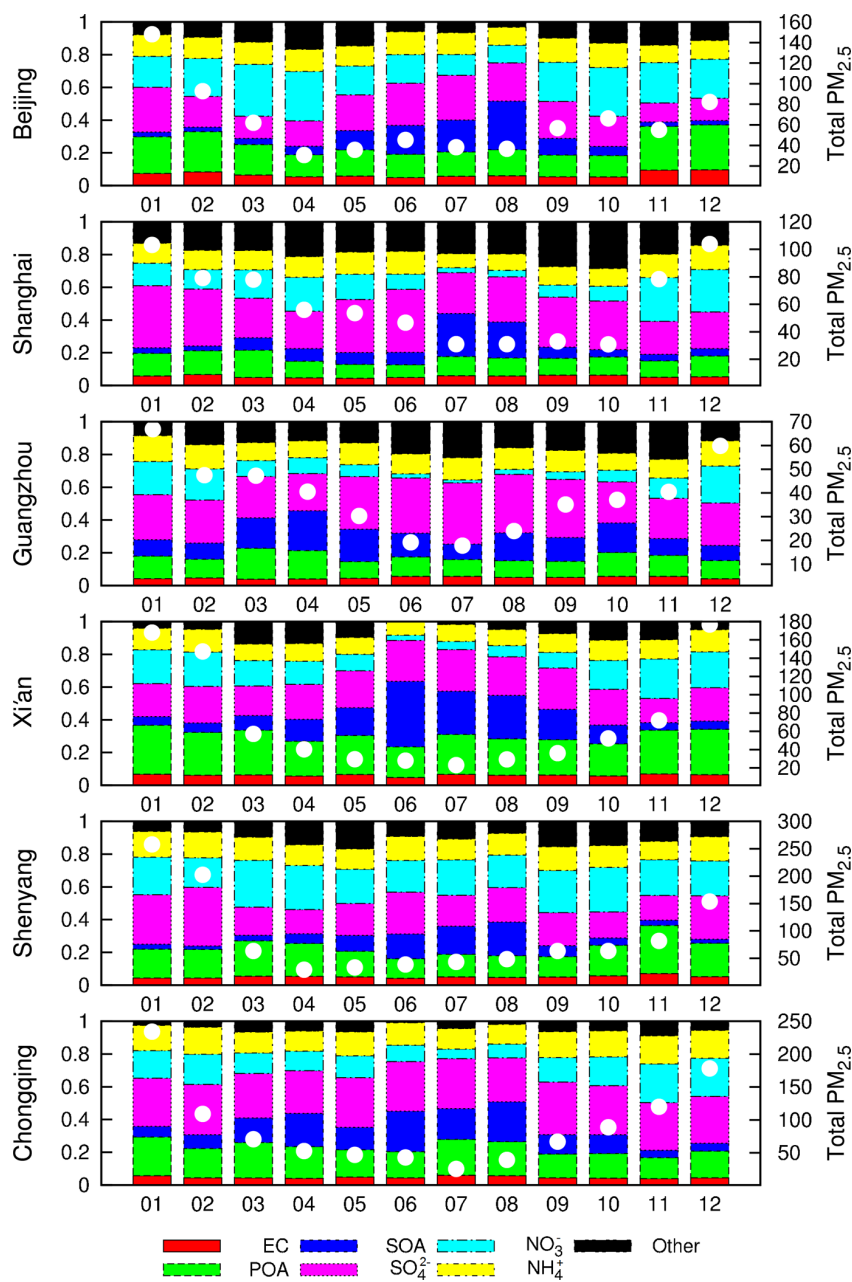

Figure 9. Contributions of different components to monthly averaged $\mathrm{PM}_{2.5}$ concentrations at selected cities in China. White circles are absolute concentrations according to right $y$ axis with unit of $\mu \mathrm{g} \mathrm{m}^{-3}$.

also play a significant role in summer PM pollution events of urban areas. In conclusion, in most cities in most seasons, episode days have more rapid formation of secondary PM components than accumulation of primary pollutants due to unfavorable weather conditions. This also suggests that controlling the emissions of secondary PM precursors needs to be considered in designing emission control strategies as in many conditions it can be more effective in reducing PM concentrations.

\section{Discussion}

Model-predicted concentrations of $\mathrm{O}_{3}$ and $\mathrm{PM}_{2.5}$ are evaluated by comparing them to ground-level observations at 422 stations in 60 cities in China for 10 months in 2013. Predicted concentrations generally agree well with observations, with the model performance statistics meeting the criteria in most
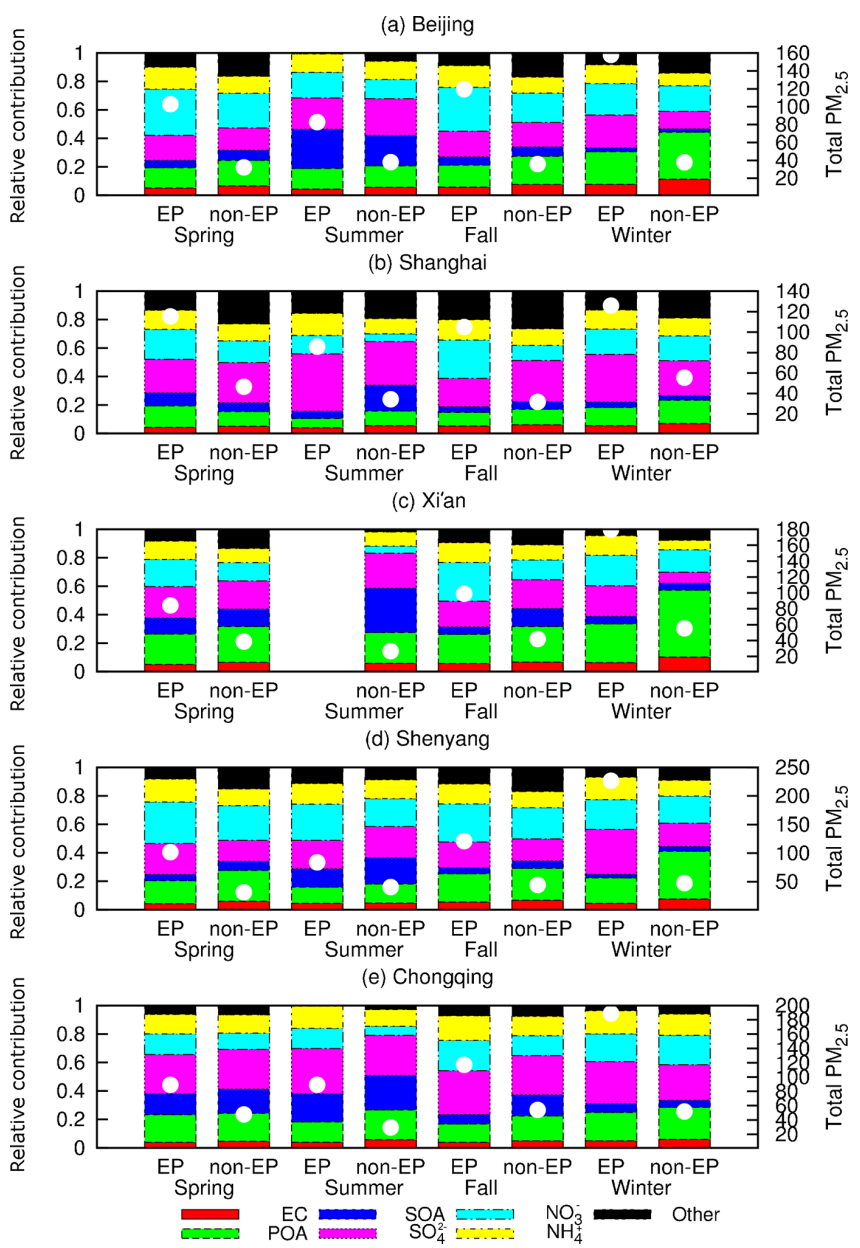

Figure 10. Comparison of $\mathrm{PM}_{2.5}$ components at episode days $\left(\mathrm{Ep},>=75 \mu \mathrm{g} \mathrm{m}^{-3}\right.$ ) and non-episode days (non-EP, $<75 \mu \mathrm{g} \mathrm{m}^{-3}$ ). White circles are absolute concentrations according to right $y$ axis with unit of $\mu \mathrm{g} \mathrm{m}^{-3}$. Note Xi' an does not have episode days in summer.

of the regions and months. Relatively large bias in modelpredicted concentrations is found in certain regions in certain months/episodes. Model bias is mainly attributed to uncertainties associated with meteorological fields, emissions, model treatment, and configurations. Further studies are still needed to continue improving the model capability in accurately predicting air quality in China.

The WRF model performance in this study is comparable to other studies (Hu et al., 2015a; Wang et al., 2010, 2014; Ying et al., 2014b; Zhang et al., 2012), but a better WRF performance was reported in Zhao et al. (2013a). Mesoscale meteorological modeling studies are also needed to improve the WRF model capability in China. In this study, some meteorological parameters are biased; for example, ground-level wind speed is consistently overpredicted and RH is more biased low in winter months (Table 1). A previous study has revealed that air pollution levels are associated with these parameters in highly polluted regions in China (Y. Wang et al., 
2014). It is also demonstrated that bias in predicted meteorological parameters by WRF contributes to bias in $\mathrm{PM}_{2.5}$ prediction (Hu et al., 2015c; Zhang et al., 2014a, b). A companion study is undergoing to evaluate the sensitivity of predictions to meteorological fields.

Uncertainties associated with emission inventory often are the major factor leading to bias in model predictions. The overall good model performance in most regions indicates general accuracy of the MEIC inventory. However, larger negative bias in $\mathrm{CO}, \mathrm{NO}_{2}$, and $\mathrm{SO}_{2}$ in $\mathrm{NW}$ (Table 4) suggests that anthropogenic emissions, including primary $\mathrm{PM}_{2.5}$, are severely underestimated in this region. Similarly, underpredictions of $\mathrm{PM}_{2.5}$ in Lhasa are also likely due to underpredictions of anthropogenic emissions, mostly likely those from residential sources. Studies have suggested that dust contributes significantly to $\mathrm{PM}_{2.5}$ in NW (J. Li et al., 2014; Shen et al., 2009). The current estimation of dust from wind erosion of natural soil surfaces in the NW is approximately $20 \mu \mathrm{g} \mathrm{m}^{-3}$ in spring and lower than $10 \mu \mathrm{g} \mathrm{m}^{-3}$ in other seasons. This relatively low estimation of $\mathrm{PM}_{2.5}$ in the $\mathrm{NW}$ of China generally agrees with the most recent global long-term $\mathrm{PM}_{2.5}$ estimation based on satellite aerosol optical depth measurements (Battelle Memorial Institute and Center for International Earth Science Information Network - CIESIN; Columbia University, 2013; de Sherbinin et al., 2014). Emissions of dust from other sources in the urban/rural areas, such as paved and unpaved road and construction activities, could be a more important factor that leads to underpredictions of mineral PM components in the NW cities. Both activity data and emission factors used to generate these area emissions should be examined carefully. Source apportionment studies based on receptor-oriented techniques should be used to differentiate the contributions from these different dust sources to further constrain the uncertainties in dust emissions.

Another important source of underprediction of $\mathrm{PM}_{2.5}$ is SOA, especially in the summer when the biases in $\mathrm{PM}_{2.5}$ predictions are larger and more SOA is expected to form due to higher VOCs emissions and higher atmospheric reactivity. While significant progress has been made to improve model predictions and the SOA module used in the current study has incorporated many of the newly found SOA formation pathways, the understanding of both gas phase and particle phase chemistry that leads to SOA formation is still very limited, and many experimental findings have yet to be incorporated by the modeling community. To constrain the uncertainties in SOA predictions, speciated measurements of SOA tracers and gas phase VOC precursors are needed along with models with detailed chemical mechanisms to represent the species. While some VOC speciation data are available, more data in different regions and episodes are needed to improve both estimation of VOC emissions (Zhang and Ying, 2011) and model predictions of SOA.

Model grid resolution also contributes to the bias in predictions. The emissions are instantly mixed into $36 \times 36 \mathrm{~km}^{2}$ grids after being released from sources. Some of the mon- itoring stations are located in urban areas near emission sources, such as traffic and industrial facilities, which could imply negative prediction biases when compared with modeled concentrations that represent average concentrations in a grid cell. Higher-resolution modeling studies are believed to more accurately capture the concentrations and to reveal finer scale spatial distribution of pollutants (Fountoukis et al., 2013; Gan et al., 2016; Joe et al., 2014; Stroud et al., 2011). The grid dilution effect theoretically has larger impact on $\mathrm{CO}$ and $\mathrm{SO}_{2}$ than on $\mathrm{O}_{3}$ and $\mathrm{PM}_{2.5}$, because $\mathrm{O}_{3}$ and secondary $\mathrm{PM}_{2.5}$ components are often formed regionally and consequently have a more uniform spatial distribution.

\section{Conclusions}

In this study, $\mathrm{O}_{3}$ and $\mathrm{PM}_{2.5}$ in China during the entire year of 2013 is simulated using an updated WRF/CMAQ model system and anthropogenic emissions from MEIC. The WRF model predicts reasonable meteorological inputs for the CMAQ model. The comparison of predicted and observed hourly $\mathrm{O}_{3}$, peak hour $\mathrm{O}_{3}$, and daily and monthly averaged $\mathrm{PM}_{2.5}$ in 60 cities shows that the current model can successfully reproduce the $\mathrm{O}_{3}$ and $\mathrm{PM}_{2.5}$ concentrations at most cities for most months of the year. Overprediction of $\mathrm{O}_{3}$ occurs at low concentration range in winter while underprediction of $\mathrm{PM}_{2.5}$ happens at low concentration range in summer. Spatially, the model has better performance in NE, NCP, central YRD, and SCB but significant underprediction biases exist for the cities in the NW region. Strong seasonal variations of $\mathrm{PM}_{2.5}$ exist and wind speed and direction play important roles in high $\mathrm{PM}_{2.5}$ events. Secondary components have more boarder distribution than primary components. Contributions of secondary PM components increase during high PM events in a number of urban areas, suggesting that secondary PM formation rates are enhanced more than the accumulation rate of primary pollutants. Overall, $\mathrm{SO}_{4}^{2-}, \mathrm{NO}_{3}^{-}$, $\mathrm{NH}_{4}^{+}$, and POA are the most important $\mathrm{PM}_{2.5}$ components. All components have the highest concentrations in winter except SOA. NCP, CEN, and SCB have more severe $\mathrm{PM}_{2.5}$ levels than YRD and PRD.

This study reports the detailed model performance of $\mathrm{O}_{3}$ and $\mathrm{PM}_{2.5}$ in China for an entire year with the public available observations nationwide in China. Although much needs to be done to improve the model performance, this study shows the capability of the model with MEIC emission in reproducing severe air pollution. The concentrations of $\mathrm{O}_{3}$, $\mathrm{PM}_{2.5}$ total mass, and its chemical components from this study will be used in future studies to understand formation mechanisms of severe air pollution episodes, investigate the effectiveness of emission control strategies, and estimate human exposure to multiple pollutants for assessing health burden of air pollution in China. 


\section{Data availability}

Data used in this manuscript can be provided upon request by e-mail to the corresponding authors Qi Ying (qying@civil.tamu.edu), and Hongliang Zhang (hlzhang@lsu.edu).

Acknowledgements. This project is partly funded by the Natural Science Foundation of Jiangsu Province (BK20150904 and BK20151041), Jiangsu Distinguished Professor Project (2191071503201), Jiangsu Six Major Talent Peak Project (2191071502101), the Startup Fund for Talent at NUIST (2243141501008), the Priority Academic Program Development of Jiangsu Higher Education Institutions (PAPD), Jiangsu Key Laboratory of Atmospheric Environment Monitoring and Pollution Control of Nanjing University of Information Science and Technology, and Jiangsu Province Innovation Platform for Superiority Subject of Environmental Science and Engineering (no. KHK1201). We would like to thank the computation resources from the Texas A\&M Supercomputing Facility (http://sc.tamu.edu/) for completing some of the model simulations reported in this study.

Edited by: J. Huang

Reviewed by: three anonymous referees

\section{References}

Aw, J. and Kleeman, M. J.: Evaluating the first-order effect of intraannual temperature variability on urban air pollution, J. Geophys. Res.-Atmos., 108, 4365, doi:10.1029/2002JD002688, 2003.

Battelle Memorial Institute and Center for International Earth Science Information Network - CIESIN - Columbia University: Global Annual Average $\mathrm{PM}_{2.5}$ Grids from MODIS and MISR Aerosol Optical Depth (AOD). NASA Socioeconomic Data and Applications Center (SEDAC), Palisades, NY, 2013.

Carter, W. P. L.: Development of the SAPRC-07 chemical mechanism, Atmos. Environ., 44, 5324-5335, 2010.

Carter, W. P. L. and Heo, G.: Development of revised SAPRC aromatics mechanisms. Final Report to the California Air Resources Board, Contracts No. 07-730 and 08-326, 12 April 2012.

de Sherbinin, A., Levy, M., Zell, E., Weber, S., and Jaiteh, M.: Using Satellite Data to Develop Environmental Indicators, Environ. Res. Lett., 9, doi:10.1088/1748-9326/9/8/08401, 2014.

Emery, C., Tai, E., and Yarwood, G.: Enhanced meteorological modeling and performance evaluation for two texas episodes, Report to the Texas Natural Resources Conservation Commission, prepared by ENVIRON, International Corp., Novato, CA, available at: http://www.tceq.state.tx.us/ assets/public/implementation/air/am/contracts/reports/mm/ EnhancedMetModelingAndPerformanceEvaluation.pdf, 2001.

EPA, U.S.: Guidance on the Use of Models and Other Analyses in Attainment Demonstrations for the 8-hour Ozone NAAQS, EPA454/R-05-002, 2005.

EPA, U.S.: Guidance on the Use of Models and Other Analyses for Demonstrating Attainment of Air Quality Goals for Ozone, $\mathrm{PM}_{2.5}$, and Regional Haze, EPA-454/B-07-002, 2007
Fountoukis, C., Koraj, Dh., Denier van der Gon, H. A. C., Charalampidis, P. E., Pilinis, C., and Pandis, S. N.: Impact of grid resolution on the predicted fine PM by a regional 3-D chemical transport model, Atmos. Environ., 68, 24-32, 2013.

Fu, T. M., Jacob, D. J., Wittrock, F., Burrows, J. P., Vrekoussis, M., and Henze, D. K.: Global budgets of atmospheric glyoxal and methylglyoxal, and implications for formation of secondary organic aerosols, J. Geophys. Res.-Atmos., 113, D15303, doi:10.1029/2007JD009505, 2008.

Gan, C.-M., Hogrefe, C., Mathur, R., Pleim, J., Xing, J., Wong, D., Gilliam, R., Pouliot, G., and Wei, C.: Assessment of the effects of horizontal grid resolution on long-term air quality trends using coupled WRF-CMAQ simulations, Atmos. Environ., 132, 207216, 2016.

Gao, Y., Zhao, C., Liu, X. H., Zhang, M. G., and Leung, L. R.: WRF-Chem simulations of aerosols and anthropogenic aerosol radiative forcing in East Asia, Atmos. Environ., 92, 250-266, 2014.

Hildebrandt, L., Donahue, N. M., and Pandis, S. N.: High formation of secondary organic aerosol from the photo-oxidation of toluene, Atmos. Chem. Phys., 9, 2973-2986, doi:10.5194/acp-92973-2009, 2009.

Hu, J., Wang, Y., Ying, Q., and Zhang, H.: Spatial and temporal variability of $\mathrm{PM}_{2.5}$ and $\mathrm{PM}_{10}$ over the North China Plain and the Yangtze River Delta, China, Atmos. Environ., 95, 598-609, 2014.

Hu, J., Wu, L., Zheng, B., Zhang, Q., He, K., CHang, Q., Li, X., Yang, F., Ying, Q., and Zhang, H.: Source contributions and regional transport of primary particulate matter in China, Environ. Pollut., 207, 31-42, 2015a.

Hu, J., Ying, Q., Wang, Y. , and Zhang, H.: Characterizing multipollutant air pollution in China: Comparison of three air quality indices, Environ. Int., 84, 17-25, 2015 b.

Hu, J., Zhang, H., Ying, Q., Chen, S.-H., Vandenberghe, F., and Kleeman, M. J.: Long-term particulate matter modeling for health effect studies in California - Part 1: Model performance on temporal and spatial variations, Atmos. Chem. Phys., 15, 34453461, doi:10.5194/acp-15-3445-2015, 2015c.

Hu, X.-M., Mz, Z., Lin, W., Zhang, H., Hu, J., Wang, Y., Xu, X., Fuentes, J. D., and Xue, M.: Impact of the Loess Plateau on the atmospheric boundary layer structure and air quality in the North China Plain: A case study, Sci. Total Environ., 499, 228-237, 2014.

Jacob, D. J. and Winner, D. A.: Effect of climate change on air quality, Atmos. Environ., 43, 51-63, 2009.

Joe, D. K., Zhang, H., DeNero, S. P., Lee, H., Chen, S. H., McDonald, B. C., Harley, R. A., and Kleeman, M. J.: Implementation of a high-resolution Source-Oriented WRF/Chem model at the Port of Oakland, Atmos. Environ., 82, 351-363, 2014.

Kondo, Y., Morino, Y., Takegawa, N., Koike, M., Kita, K., Miyazaki, Y., Sachse, G. W., Vay, S. A., Avery, M. A., Flocke, F., Weinheimer, A. J., Eisele, F. L., Zondlo, M. A., Weber, R. J., Singh, H. B., Chen, G., Crawford, J., Blake, D. R., Fuelberg, H. E., Clarke, A. D., Talbot, R. W., Sandholm, S. T., Browell, E. V., Streets, D. G., Liley, B.: Impacts of biomass burning in Southeast Asia on ozone and reactive nitrogen over the western Pacific in spring, J. Geophys. Res.-Atmos., 109, D15S12, doi:10.1029/2003JD004203, 2004. 
Kurokawa, J., Ohara, T., Morikawa, T., Hanayama, S., JanssensMaenhout, G., Fukui, T., Kawashima, K., and Akimoto, H.: Emissions of air pollutants and greenhouse gases over Asian regions during 2000-2008: Regional Emission inventory in ASia (REAS) version 2, Atmos. Chem. Phys., 13, 11019-11058, doi:10.5194/acp-13-11019-2013, 2013.

Lei, Y., Zhang, Q., Nielsen, C., and He, K.: An inventory of primary air pollutants and $\mathrm{CO}_{2}$ emissions from cement production in China, 1990-2020, Atmos. Environ., 45, 147-154, 2011.

Li, J., Cleveland, M., Ziemba, L. D., Griffin, R. J., Barsanti, K. C., Pankow, J. F., and Ying, Q.: Modeling regional secondary organic aerosol using the Master Chemical Mechanism, Atmos. Environ., 102, 52-61, 2015.

Li, J., Wang, G., Aggarwal, S.G., Huang, Y., Ren, Y., Zhou, B., Singh, K., Gupta, P. K., Cao, J., and Zhang, R.: Comparison of abundances, compositions and sources of elements, inorganic ions and organic compounds in atmospheric aerosols from Xi' an and New Delhi, two megacities in China and India, Sci. Total Environ., 476-477, 485-495, 2014.

Li, M., Zhang, Q., Streets, D. G., He, K. B., Cheng, Y. F., Emmons, L. K., Huo, H., Kang, S. C., Lu, Z., Shao, M., Su, H., Yu, X., and Zhang, Y.: Mapping Asian anthropogenic emissions of nonmethane volatile organic compounds to multiple chemical mechanisms, Atmos. Chem. Phys., 14, 5617-5638, doi:10.5194/acp14-5617-2014, 2014

Li, X., Zhang, Q., Zhang, Y., Zheng, B., Wang, K., Chen, Y., Wallington, T.J., Han, W., Shen, W., Zhang, X., and He, K.: Source contributions of urban PM2.5 in the Beijing-TianjinHebei region: Changes between 2006 and 2013 and relative impacts of emissions and meteorology, Atmos. Environ., 125, 229239, 2015

Lin, Y. H., Zhang, H., Pye, H. O., Zhang, Z., Marth, W. J., Park, S., Arashiro, M., Cui, T., Budisulistiorini, S. H., Sexton, K. G., Vizuete, W., Xie, Y., Luecken, D. J., Piletic, I. R., Edney, E. O., Bartolotti, L. J., Gold, A., and Surratt, J. D.: Epoxide as a precursor to secondary organic aerosol formation from isoprene photooxidation in the presence of nitrogen oxides, Proc. Natl. Acad. Sci., 110, 6718-6723, 2013.

Lin, X. H., Zhang, Y., Cheng, S.-H., Xing, J., Zhang, Q., Streets, D. G., Jang, C., Wang, W., and Hao, J.: Understanding of regional air pollution over China using CMAQ, part I performance evaluation and seasonal variation, Atmos. Environ., 44, 2415-2426, 2010

Liu, X. Y., Zhang, Y., Zhang, Q., and He, M. B.: Application of online-coupled WRF/Chem-MADRID in East Asia: Model evaluation and climatic effects of anthropogenic aerosols, Atmos. Environ., 124, 321-336, 2016.

Menon, S., Unger, N., Koch, D., Francis, J., Gerrett, T., Sednev, I., Shindell, D., and Streets, D.: Aerosol climate effects and air quality impacts from 1980 to 2030, Environ. Res. Lett., 3, 024004, doi:10.1088/1748-9326/3/2/024004, 2008.

Ng, N. L., Kroll, J. H., Chan, A. W. H., Chhabra, P. S., Flagan, R. C., and Seinfeld, J. H.: Secondary organic aerosol formation from $m$-xylene, toluene, and benzene, Atmos. Chem. Phys., 7, 3909-3922, doi:10.5194/acp-7-3909-2007, 2007.

Pöschl, U.: Atmospheric aerosols: Composition, transformation, climate and health effects, Angew. Chem. Int. Edit., 44, 7520 7540, 2005 .
Pui, D. Y. H., Chen, S.-C., and Zuo, Z.: $\mathrm{PM}_{2.5}$ in China: Measurements, sources, visibility and health effects, and mitigation, Particuology, 13, 1-26, 2014.

Qiao, X., Tang, Y., Hu, J., Zhang, S., Li, J., Kota, S. H., Wu, L., Gao, H., Zhang, H., and Ying, Q.: Modeling dry and wet deposition of sulfate, nitrate, and ammonium ions in Jiuzhaigou National Nature Reserve, China using a source-oriented CMAQ model: Part I. Base case model results, Sci. Total Environ., 532, 831839, 2015.

Shen, Z., Cao, J., Arimoto, R., Han, Z., Zhang, R., Han, Y., Liu, S., Okuda, T., Nakao, S., and Tanaka, S.: Ionic composition of TSP and $\mathrm{PM}_{2.5}$ during dust storms and air pollution episodes at Xi'an, China, Atmos. Environ., 43, 2911-2918, 2009.

Stroud, C. A., Makar, P. A., Moran, M. D., Gong, W., Gong, S., Zhang, J., Hayden, K., Mihele, C., Brook, J. R., Abbatt, J. P. D., and Slowik, J. G.: Impact of model grid spacing on regionaland urban- scale air quality predictions of organic aerosol, Atmos. Chem. Phys., 11, 3107-3118, doi:10.5194/acp-11-31072011, 2011.

Sun, Y., Jiang, Q., Wang, Z., Fu, P., Li, J., Yang, T., and Yin, Y.: Investigation of the sources and evolution processes of severe haze pollution in Beijing in January 2013, J. Geophys. Res.-Atmos., 119, 2014JD021641, doi:10.1002/2014JD021641, 2014.

Tao, J., Gao, J., Zhang, L., Zhang, R., Che, H., Zhang, Z., Lin, Z., Jing, J., Cao, J., and Hsu, S.-C.: $\mathrm{PM}_{2.5}$ pollution in a megacity of southwest China: source apportionment and implication, Atmos. Chem. Phys., 14, 8679-8699, doi:10.5194/acp-14-86792014, 2014.

Tao, M., Chen, L., Xiong, X., Zhang, M., Ma, P., Tao, J., and Wang, Z.: Formation process of the widespread extreme haze pollution over northern China in January 2013: Implications for regional air quality and climate, Atmos. Environ., 98, 417-425, 2014.

Wang, D., Hu, J., Xu, Y., Lv, D., Xie, X., Kleeman, M. J., Xing, J., Zhang, H., and Ying, Q.: Source contributions to primary and secondary inorganic particulate matter during a severe wintertime $\mathrm{PM}_{2.5}$ pollution episode in Xi' an, China, Atmos. Environ., 97, 182-194, 2014.

Wang, L., Jang, C., Zhang, Y., Wang, K., Zhang, Q., Streets, D., Fu, J., Lei, Y., Schreifels, J., He, K., Hao, J., Lam, Y.-F., Lin, J., Meskhidze, N., Voorhees, S., Evarts, D., and Phillips, S.: Assessment of air quality benefits from national air pollution control policies in China. Part I: Background, emission scenarios and evaluation of meteorological predictions, Atmos. Environ., 44, 3442-3448, 2010.

Wang, L. T., Wei, Z., Yang, J., Zhang, Y., Zhang, F. F., Su, J., Meng, C. C., and Zhang, Q.: The 2013 severe haze over southern Hebei, China: model evaluation, source apportionment, and policy implications, Atmos. Chem. Phys., 14, 3151-3173, doi:10.5194/acp-14-3151-2014, 2014.

Wang, S. W., Zhang, Q., Streets, D. G., He, K. B., Martin, R. V., Lamsal, L. N., Chen, D., Lei, Y., and Lu, Z.: Growth in $\mathrm{NO}_{x}$ emissions from power plants in China: bottom-up estimates and satellite observations, Atmos. Chem. Phys., 12, 4429-4447, doi:10.5194/acp-12-4429-2012, 2012.

Wang, S. X., Xing, J., Chatani, S., Hao, J., Klimont, Z., Cofala, J., and Amann, M.: Verification of anthropogenic emissions of China by satellite and ground observations, Atmos. Environ., 45, 6347-6358, 2011. 
Wang, Y., Ying, Q., Hu, J. and Zhang, H.: Spatial and temporal variations of six criteria air pollutants in 31 provincial capital cities in China during 2013-2014, Environ. Int., 73, 413-422, 2014.

Wiedinmyer, C., Akagi, S. K., Yokelson, R. J., Emmons, L. K., AlSaadi, J. A., Orlando, J. J., and Soja, A. J.: The Fire INventory from NCAR (FINN): a high resolution global model to estimate the emissions from open burning, Geosci. Model Dev., 4, 625641, doi:10.5194/gmd-4-625-2011, 2011.

Ying, Q., Cureno, I. V., Chen, G., Ali, S., Zhang, H., Malloy, M., Bravo, H. A., and Sosa, R.: Impacts of Stabilized Criegee Intermediates, surface uptake processes and higher aromatic secondary organic aerosol yields on predicted $\mathrm{PM}_{2.5}$ concentrations in the Mexico City Metropolitan Zone, Atmos. Environ., 94, 438-447, 2014a.

Ying, Q., Wu, L., and Zhang, H.: Local and inter-regional contributions to $\mathrm{PM}_{2.5}$ nitrate and sulfate in China, Atmos. Environ., 94, 582-592, 2014b.

Ying, Q., Li, J., and Kota, S. H.: Significant Contributions of Isoprene to Summertime Secondary Organic Aerosol in Eastern United States, Environ. Sci. Technol., 49, 7834-7842, 2015.

Zhang, B., Wang, Y., and Hao, J.: Simulating aerosol-radiationcloud feedbacks on meteorology and air quality over eastern China under severe haze conditionsin winter, Atmos. Chem. Phys., 15, 2387-2404, doi:10.5194/acp-15-2387-2015, 2015.

Zhang, H. and Ying, Q.: Secondary Organic Aerosol Formation and Source Apportionment in Southeast Texas, Atmos. Environ., 45, 3217-3227, 2011.

Zhang, H., Li, J., Ying, Q., Yu, J. Z., Wu, D., Cheng, Y., He, K., and Jiang, J.: Source apportionment of $\mathrm{PM}_{2.5}$ nitrate and sulfate in China using a source-oriented chemical transport model, Atmos. Environ., 62, 228-242, 2012.

Zhang, H., Chen, G., Hu, J., Chen, S.H., Wiedinmyer, C., Kleeman, M. J., and Ying, Q.: Evaluation of a seven-year air quality simulation using the Weather Research and Forecasting (WRF)/Community Multiscale Air Quality (CMAQ) models in the eastern United States, Sci. Total Environ., 473-474, 275-285, 2014a.
Zhang, H., Hu, J., Kleeman, M., and Ying, Q.: Source apportionment of sulfate and nitrate particulate matter in the Eastern United States and effectiveness of emission control programs, Sci. Total Environ., 490, 171-181, 2014 b.

Zhang, H., Wang, Y., Hu, J., Ying, Q., and Hu, X.-M.: Relationships between meteorological parameters and criteria air pollutants in three megacities in China, Environ. Res., 140, 242-254, 2015.

Zhang, X., Cappa, C. D., Jathar, S. H., McVay, R. C., Ensberg, J. J., Kleeman, M. J., and Seinfeld, J. H.: Influence of vapor wall loss in laboratory chambers on yields of secondary organic aerosol, Proc. Natl. Acad. Sci. USA, 111, 5802-5807, 2014.

Zhang, Y., Zhang, X., Wang, L., Zhang, Q., Duan, F., and He, K.: Application of WRF/Chem over East Asia: Part I. Model evaluation and intercomparison with MM5/CMAQ, Atmos. Environ., 124, 285-300, 2016.

Zhao, B., Wang, S. X., Dong, X., Wang, J., Duan, L., Fu, X., Hao, J., and $\mathrm{Fu}, \mathrm{J} .:$ Environmental effects of the recent emission changes in China: implications for particulate matter pollution and soil acidification, Environ. Res. Lett., 8, 024031, doi:10.1088/17489326/8/2/024031, 2013a.

Zhao, B., Wang, S. X., Wang, J., Fu, J., Liu, T., Xu, J., Fu, X., and Hao, J.: Impact of national $\mathrm{NO}_{x}$ and $\mathrm{SO}_{2}$ control policies on particulate matter pollution in China, Atmos. Environ., 77, 453463, $2013 \mathrm{~b}$.

Zheng, B., Huo, H., Zhang, Q., Yao, Z. L., Wang, X. T., Yang, X. F., Liu, H., and He, K. B.: High-resolution mapping of vehicle emissions in China in 2008, Atmos. Chem. Phys., 14, 9787-9805, doi:10.5194/acp-14-9787-2014, 2014.

Zheng, B., Zhang, Q., Zhang, Y., He, K. B., Wang, K., Zheng, G. J., Duan, F. K., Ma, Y. L., and Kimoto, T.: Heterogeneous chemistry: a mechanism missing in current models to explain secondary inorganic aerosol formation during the January 2013 haze episode in North China, Atmos. Chem. Phys., 15, 2031-2049, doi:10.5194/acp-15-2031-2015, 2015. 